\title{
MARCAS E DIVISÃO DE TRABALHO NA REDE DE PRODU- ÇÃO AUTOMOBILÍSTICA: O CASO MAN LATIN AMERICA.
} BRANDS AND DIVISION OF LABOR IN THE AUTOMOBILE PRODUCTION NETWORK: THE MAN LATIN AMERICA CASE.

MARQUES ET DIVISION DU TRAVAIL DANS LE RESEAU DE PRODUCTION AUTOMOBILE: LE CAS MAN LATIN AMERICA.

\section{MARCAS Y DIVISIÓN DE TRABAJO EN LA RED DE PRODUCCIÓN} AUTOMOTRIZ: EL CASO MAN LATIN AMERICA.

\section{Diego Moreira Maggi}

RESUMO: O objetivo do artigo é analisar como a gestão da imagem das marcas participa das múltiplas dimensões da estratégia das corporações, desde a concepção até a fabricação dos produtos, passando pela publicidade. Para tal, é apresentado o caso da MAN Latin America, empresa do Grupo Volkswagen que comercializa caminhões e ônibus de ambas as marcas: MAN e Volkswagen. Sua fábrica, localizada no município de Resende, no Estado do Rio de Janeiro, foi construída a partir do modelo de consórcio modular. Este artigo busca demonstrar como há uma divisão de trabalho pela qual as firmas fornecedoras de peças são responsáveis diretamente pela fabricação dos veículos, enquanto que a MAN Latin America concentra-se em atividades de controle de informações, marketing, design, pesquisa e desenvolvimento (P\&D) e, no cruzamento dessas atividades, gestão de marcas. Tal divisão parece compor a tendência de reconfiguração das redes globais de produção (RGP) pela qual a concentração de marcas, propriedade intelectual e demais ativos intangíveis exercem cada vez mais importância para a acumulação capitalista.

Palavras-chave: marca; indústria automobilística; estratégia corporativa; redes globais de produção.

\footnotetext{
* Mestre em Sociologia pelo Programa de Pós-Graduação em Sociologia e Antropologia da Universidade Federal do Rio de Janeiro (UFRJ); Técnico do Departamento Intersindical de Estatística e Estudos Socioeconômicos (DIEESE) e Gerente de Projetos do Instituto Municipal de Informação e Pesquisa Darcy Ribeiro, Maricá, RJ, Brasil; E-mail: moreiramaggi@gmail.com
} 
ABSTRACT: The objective of this article is to analyze how brand image management participates in the multiple dimensions of corporate strategy, from conception to product manufacturing, through advertising. To this end, the case of MAN Latin America, a Volkswagen Group company that markets trucks and buses of both $M A N$ and Volkswagen brands, is presented. Its plant, located in the municipality of Resende, in the State of Rio de Janeiro, was built from the modular consortium model. This article seeks to demonstrate how there is a division of labor for which the parts supplier companies are directly responsible for the manufacturing of the vehicles, while MAN Latin America focuses on information control, marketing, design, research and development $(R \& D)$ and, at the intersection of these activities, brand management. Such a division seems to be part of the reconfiguration trend of global production networks (GPN) whereby the concentration of brands, intellectual property and other intangible assets are increasingly important for capitalist accumulation.

Keywords: brand; auto industry; corporate strategy; global production networks.

RÉSUMÉ: L'objectif de cet article est d'analyser la manière dont la gestion de l'image de marque participe aux multiples dimensions de la stratégie d'entreprise, de la conception à la fabrication du produit, en passant par la publicité. À cette fin, le cas de MAN Latin America, une société du groupe Volkswagen qui commercialise des camions et des bus des deux marques, MAN et Volkswagen, est présenté. Son usine, située dans la municipalité de Resende, dans la province de Rio de Janeiro, a été construite sur le modèle du consortium modulaire. Cet article cherche à démontrer comment il existe une division du travail pour laquelle les fournisseurs de pièces sont directement responsables de la fabrication des véhicules, tandis que MAN Latin America se concentre sur le contrôle de l'information, le marketing, la conception, la recherche et développement ( $\& \& D)$ et, à l'intersection de ces activités, la gestion de la marque. Cette division semble faire partie de la reconfiguration des réseaux de production mondiaux (RPM), dans lesquels la concentration des marques, de la propriété intellectuelle et d'autres actifs incorporels est de plus en plus importante pour l'accumulation capitaliste.

Mots-clés: marque; industrie automobile; stratégie d'entreprise; réseaux de production mondiaux.

RESUMEN: El objetivo del artículo es analizar cómo la gestión de la imagen de las marcas participa de las múltiples dimensio- 
nes de la estrategia de las corporaciones, desde la concepción hasta la fabricación de los productos, pasando por la publicidad. Para ello, se presenta el caso de MAN Latin America, empresa del Grupo Volkswagen que comercializa camiones y autobuses de ambas marcas: MAN y Volkswagen. Su fábrica, ubicada en el municipio de Resende, en la provincia de Río de Janeiro, fue construida a partir del modelo de consorcio modular. Este artículo busca demostrar cómo hay una división de trabajo por la cual las empresas proveedoras de piezas son responsables directamente por la fabricación de los vehiculos, mientras que MAN Latin America se concentra en actividades de control de información, marketing, diseño, investigación y desarrollo (I\&D) y, en el cruce de esas actividades, gestión de marcas. Tal división parece componer la tendencia de reconfiguración de las redes globales de producción (RGP) por la cual la concentración de marcas, propiedad intelectual y demás activos intangibles ejercen cada vez más importancia para la acumulación capitalista.

Palabras clave: marca; industria automotriz; estrategia corporativa; redes globales de producción.

\section{INTRODUÇÃO}

Este artigo é produto de uma pesquisa realizada no âmbito do Mestrado no Programa de Pós-graduação de Sociologia e Antropologia da Universidade Federal do Rio de Janeiro (PPGSA/UFRJ) ${ }^{2}$, especificamente no grupo de pesquisa Desenvolvimento, Trabalho e Ambiente (DTA). Seu objetivo foi compreender como uma corporação elabora estratégias que manejam suas marcas e delas extraem valor, com especial atenção ao trabalho realizado para além do âmbito da fábrica, como as atividades de marketing. A marca é um fenômeno conhecido desde a Antiguidade, quando artesãos inscreviam selos, nomes ou siglas nos produtos, de maneira a atestar sua origem e qualidade (Norberto, 2004). O termo em inglês, brand, deriva do nórdico antigo brandr, que significa "queimar", em referência ao ato de criadores de gado de marcar seus animais com brasa (Keller, 2013, p. 30). As marcas foram ganhando importância a partir da revolução industrial, principalmente na segunda metade do século XX. Desde a década de 1990, elas são centrais tanto para

2 Dissertação "Criando valor para além da fábrica? Um estudo sobre a estratégia de marca da MAN Latin America", orientada pelo Prof. Dr. Rodrigo Santos, financiada pelo Conselho Nacional de Desenvolvimento Científico e Tecnológico (CNPq) e defendida em janeiro de 2018. 
os processos de distinção social e de constituição de identidades, quanto para os processos de acumulação de capital. "Grande parte das pessoas não sabe qual é a marca do detergente que usa, embora resista em tomar um refrigerante, ou uma cerveja, que não seja da marca que prefere" (Norberto, 2004, p. 204).

O objeto estudado foi o caso da MAN Latin America, empresa que atua no mercado, principalmente brasileiro, de caminhões e ônibus, e que pertence ao Grupo Volkswagen. Da sua fábrica, localizada na cidade de Resende, no estado do Rio de Janeiro, saem produtos de duas marcas: MAN Truck \& Bus e Volkswagen Caminhões e Ônibus. O Grupo Volkswagen possui ainda uma terceira marca de caminhões, a Scania, e outras dez marcas da indústria automobilística, a saber: Volkswagen (veículos de passageiros), Audi, Seat, Bentley, Bugatti, Skoda, Lamborghini, Ducati, Porsche e Volkswagen Veículos Comerciais.

Este artigo traz apenas um recorte dos resultados da pesquisa, buscando demonstrar como o trabalho realizado na rede de produção de caminhões e ônibus é dividido entre, por um lado, processos de fabricação e, por outro, controle de informações, marketing, design, pesquisa e desenvolvimento (P\&D), e no cruzamento de todas essas atividades, controle e gestão de marcas (Coe; Hess, 2013).

Recorreu-se a uma metodologia basicamente qualitativa. Considerando a dificuldade de acesso a setores executivos de grandes corporações, foram utilizadas três entrevistas estratégicas, em formato semiestruturado, realizadas ao longo de 2016 pelo grupo DTA. Foram entrevistados o Gerente de Marketing, João Herrmann, o Diretor de Relações Institucionais da MAN Latin America, Marcos Saltini, e a proprietária de uma empresa assessoria de comunicação para a indústria automotiva, Katia Visentainer. Também foram reunidas matérias em revistas especializadas, como Carga Pesada e Automotive Business, além de documentos, relatórios e press releases da Associação Nacional de Fabricantes de Veículos Automotores (ANFAVEA), da Volkswagen AG e da MAN Latin America.

A pesquisa - e este artigo - buscou se inserir no debate a respeito das transformações contemporâneas da produção capitalista. Desde a reestruturação produtiva dos anos 1970, autores de múlti- 
plas áreas do conhecimento se esforçam para compreender as características dessas transformações e seus possíveis desdobramentos políticos e culturais.

Diversos foram os conceitos cunhados na tentativa de sintetizar o 'espírito' dos novos tempos, como "capitalismo informacional" (Castells, 1999), "sociedade pós-industrial” (De Masi, 2000), "pós-modernidade" (Negri; Hardt, 2001), "capitalismo cognitivo" (Gorz, 2005), "economia da cultura" (Yúdice, 2004), "economia criativa" (Landry, 2011), dentre outros. Em maior ou menor grau, todos esses conceitos foram pensados a partir da constatação do crescimento de postos de trabalho no setor de serviços, em detrimento do setor industrial.

Mais recentemente, muito se discute sobre a chamada indústria 4.0 e seus impactos. $O$ termo possui múltiplas definições, mas, no geral, se refere ao impacto da inserção de novas tecnologias na produção industrial, destacando-se "sistemas ciber-físicos (CPS), Big Data Analytics, computação em nuvem, Internet das Coisas (IoT) e Internet dos serviços (IoS), impressão 3D e outras formas de manufatura aditiva, inteligência artificial, digitalização, colheita de energia (energy harvesting) e realidade aumentada" (IEDI, 2017, p. 2).

Para os mais entusiastas, todas essas transformações seriam indicativas da ascensão de uma nova economia - e até mesmo de uma nova sociedade - na qual o trabalho humano estaria sendo libertado das atribuições manuais e fabris para se dedicar a atividades "imateriais" (Gorz, 2005; Lazzarato, 2001; Negri; Hardt, 2001) ou "criativas" (Landry, 2011).

Uma grande multiplicidade de estudos foi realizada sobre os impactos da inserção das novas tecnologias e de novos modos de organização na produção e nas relações de trabalho. Os modelos teóricos da cadeia produtiva de valor (CGV) e, principalmente, da rede global de produção (RGP) são produtos do esforço de mapear o conjunto de atividades, empresas e outros atores sociais envolvidos em todo processo produtivo de mercadorias, desde a fábrica terceirizada até os escritórios administrativos de empresas líderes. Porém, ainda há pouco conhecimento sociológico a respeito do trabalho corporativo que existe para além da fábrica. Isto é, além da fabricação na linha de 
montagem, a mercadoria - em especial aquela submetida a uma marca - passa por processos de trabalho de desenvolvimento e divulgação. Porém, esse tipo de trabalho, que denominamos mental ou intelectual (Carchedi, 2011), ainda é um tanto nebuloso para a sociologia.

Este artigo pretende mostrar como a divisão de trabalho na rede de produção de caminhões e ônibus mapeada pela pesquisa aponta que as transformações (tecnológicas e organizacionais) na produção industrial afetam de maneira diferenciada os membros componentes das redes globais de produção. Essas transformações são, ao mesmo tempo, causa e consequência do processo de divisão na qual empresas líderes possuem controle de marcas e propriedade intelectual e outras empresas especializam-se na fabricação das mercadorias.

\section{CONSIDERAÇÕES TEÓRICAS SOBRE MARCAS}

Em uma definição mais simples e consensual, as marcas são conjuntos de signos capazes de remeter a qualidades, locais, pessoas, empresas, e até mesmo a valores sociais (Norberto, 2010). Enquanto fenômeno social, a marca passou por um processo de transformação, sendo primeiramente utilizada para atestar qualidade e distinção de produtos, assumindo novas características e funções ao longo do século XX. Norberto (2004), Willmott (2010) e Lury (2004) argumentam que, durante a expansão geográfica do capitalismo - segunda metade do século XIX e começo do século XX - surgiram as primeiras grandes marcas de mercadorias produzidas em massa e até então ordinárias, como sabonetes, cereais, sopas, bebidas, etc. O branding foi uma ferramenta significativa para a expansão da atividade de algumas empresas em níveis nacional e internacional, proporcionando maior competitividade através da diferenciação em relação aos concorrentes e aos produtos locais.

Em meados do século XX, o fenômeno passou por uma guinada, passando a abarcar toda uma gama de produtos e serviços e, principalmente a partir da década de 1980, toda a corporação. A recuperação econômica da Europa Ocidental e do Japão e a saturação dos mercados internos das principais economias capitalistas após a Segunda Guerra Mundial impulsionaram as empresas a internacio- 
nalizarem suas atividades (Harvey, 1989, p. 135). Nesse contexto, as mercadorias padronizadas e produzidas em massa passaram a ter uma desvantagem frente aos produtos diferenciados, submetidos ao branding, com designs inovadores e com reputação de alta qualidade (Kaplinsky, 1998, p. 25). Ademais, essa intensificação da competição diz respeito também à concorrência entre empresas que já possuíam marcas consolidadas. Nos termos de Willmott (2010), esse momento histórico corresponde a uma "segunda fase" da marca, na qual o branding é cada vez mais caracterizado por transmitir símbolos e estilos de vida, resultando num diferencial competitvo em relação aos produtos e serviços de marcas concorrentes que somente atestavam qualidade. A construção de uma personalidade ou de uma reputação da marca cria um efeito sobre o comportamento de engajamento, confiança e fidelidade por parte do consumidor, denominado brand equity (Willmott, 2010, p. 519).

Conforme foram se dando os processos de reestruturação produtiva das décadas de 1970 e 1980, empresas desenvolvedoras de produtos - as empresas líderes ou compradoras, se quisermos usar os termos das CGVs (Gereffi, 2010; Gereffi; Humphrey; Sturgeon, 2005) - foram cada vez mais se especializando em atividades em torno do branding, como marketing, design, publicidade e inovação tecnológica, em detrimento do controle direto sobre o processo produtivo, que passou a ser terceirizado (Coe; Hess, 2013; Ermann, 2008; Willmott, 2010).

Esse processo foi intensificado com a financeirização da economia por volta das décadas de 1980 e 1990, proporcionada por políticas neoliberais de desregulação dos mercados financeiros e pelo advento de novas tecnologias da informação e de comunicação. À medida que as tomadas de decisão corporativas foram se tornando cada vez mais pautadas pelos interesses dos acionistas, o investimento em construção de brand equity foi demonstrando ter uma taxa de retorno alta e rápida. A financeirização propiciou o surgimento de uma "terceira fase" do branding, na qual o efeito da imagem da marca, o brand equity, passou a ser traduzido em valor monetário, o brand value (Willmott, 2010, p. 523). Hoje, a marca é indicador de desempenho das empresas no mercado financeiro, participando da constituição 
de ativos intangíveis/imateriais ou, nos termos de Norberto (2004, p. 207), "ativos simbólicos". A influência desses ativos pode ser observada em momentos de aquisição interfirmas, quando o preço de aquisição ultrapassa substancialmente o valor dos ativos tangíveis.

Um ponto importante na literatura especializada é a maneira pela qual a relação entre empresas e consumidores foi alterada pelas marcas. Elas interagem com o universo simbólico das sociedades, participando dos processos de distinção social (Norberto, 2004, p. 204) e conectando identidades de grupos aos interesses empresariais (Ermann, 2008, p. 2). Os consumidores, porém, não são seres passivos, como páginas em branco, totalmente sujeitos à influência da publicidade; eles possuem desejos inconscientes que precisam ser captados pelos 'marqueteiros' através de métodos qualitativos e traduzidos em inovações materiais nos produtos (Lury, 2004; Norberto, 2004). Trata-se, portanto, de um 'via de mão dupla': as corporações se alimentam das identidades e dos processos de distinção, ao mesmo tempo em que os influencia.

A produção simbólica em torno do branding constrói uma linha de coerência em meio às constantes inovações de produto exigidas pela dinâmica de mercado e cria laços de confiança entre a empresa e um determinado grupo social. Por outro lado, essa mesma produção simbólica impõe limitações à atuação das empresas, pois é preciso haver coerência entre as características físicas dos produtos, a comunicação empresarial, as estratégias de produção, os valores/ símbolos mobilizados pela marca e as necessidades dos grupos de consumidores em potencial.

Ademais, essa "arquitetura simbólica" (Norberto, 2004, p. 205) acaba possuindo uma existência relativamente autônoma, o que limita a capacidade das empresas de alterá-la. Os consumidores participam ativamente na disseminação e na construção de uma narrativa a respeito da marca, porém, esse ativismo se torna uma faca de dois gumes: eles são capazes de construir ou de destruir o brand equity (Willmott, 2010, p. 526). Portanto, a interação entre múltiplas marcas de um mesmo grupo corporativo ou a inserção de uma delas em um novo segmento necessita de sinergias adequadas, correndo-se o risco de enfraquecer os elos de identificação com seu público. 
Marcas e divisão de trabalho na rede de produção automobilística: o caso MAN Latin America.

\section{APRESENTANDO A MAN LATIN AMERICA}

A MAN Latin America é uma empresa do mercado de caminhões e ônibus pertencente à holding Volkswagen Truck \& Bus, que por sua vez pertence ao Grupo Volkswagen. Apesar de fazer parte de um conglomerado transnacional que tem origem e sede na Alemanha, a MAN Latin America Ltda. é uma empresa brasileira. Trata-se da única empresa do Grupo Volkswagen que desenvolve e vende caminhões e ônibus de marca Volkswagen no mundo, produzidos na sua fábrica de Resende, no Estado do Rio de Janeiro. Foi inclusive responsável pelo desenvolvimento dos primeiros modelos no Brasil (Saltini, 2016, p. 25; Man Latin America, 2004).

A história da empresa remete ao ano de 1958, quando foi criada a Simca do Brasil, subsidiária brasileira da franco-italiana Simca. A empresa foi então adquirida pelo grupo estadunidense Chrysler, em 1966, passando a se chamar Chrysler do Brasil (Man Latin America, 2017a). Em 1969, foi iniciada a fabricação dos caminhões da marca Dodge em São Bernardo do Campo. Dez anos depois, a Volkswagen AG adquiriu a Chrysler do Brasil, alterando a razão social da empresa para Volkswagen Caminhões Ltda. Em 2008, a empresa foi adquirida pelo grupo MAN SE, passando ao seu nome atual. Desde então, ela comercializa produtos de ambas as marcas MAN e Volkswagen. Segundo ranking da consultoria Interbrand, a MAN é a décima nona marca mais valiosa da Alemanha (Interbrand, 2015), enquanto que a Volkswagen é a vigésima marca mais valiosa do mundo (Interbrand, 2016).

A MAN Latin America foi líder no mercado brasileiro de caminhões por treze anos consecutivos até 2016, ano em que a primeira posição voltou a pertencer à Mercedes-Benz do Brasil (Revista Carga Pesada, 2017). Entretanto, em uma análise mais detida dos licenciamentos nacionais, isto é, dos veículos produzidos e autorizados a circular em território nacional, podemos observar que a distância entre as duas concorrentes é pequena: em 2016, a Mercedes-Benz do Brasil licenciou 13.905 caminhões nacionais, número que representa $27,9 \%$ do total de licenciamentos; enquanto isso, a MAN Latin America licenciou 13.686, ou 27,4\% do total (cf. Gráfico 1). 
No que se refere ao mercado de ônibus, a MAN Latin America permanece há mais de uma década na segunda posição, também atrás da Mercedes-Benz do Brasil: em 2016, a primeira licenciou 1.798 ônibus nacionais, representando $16,1 \%$ do total, enquanto que a segunda foi responsável por 6.068 licenciamentos, ou 38,3\% do total (cf. Gráfico 2).

Além do mercado nacional, a MAN Latin America exporta produtos para trinta países da América Latina, África e Oriente Médio (Revista Carga Pesada, 2017). Em 2016, a empresa exportou 4.028 caminhões e 2.548 ônibus, segundo dados da Associação Nacional de Fabricantes de Veículos Automotores, AFAVEA (2017a).

\section{Gráfico 1}

Quantidade de CAMINHÕES nacionais licenciados pela MAN Latin America e pela Mercedes-Benz e suas respectivas taxas de participação no total de licenciamentos

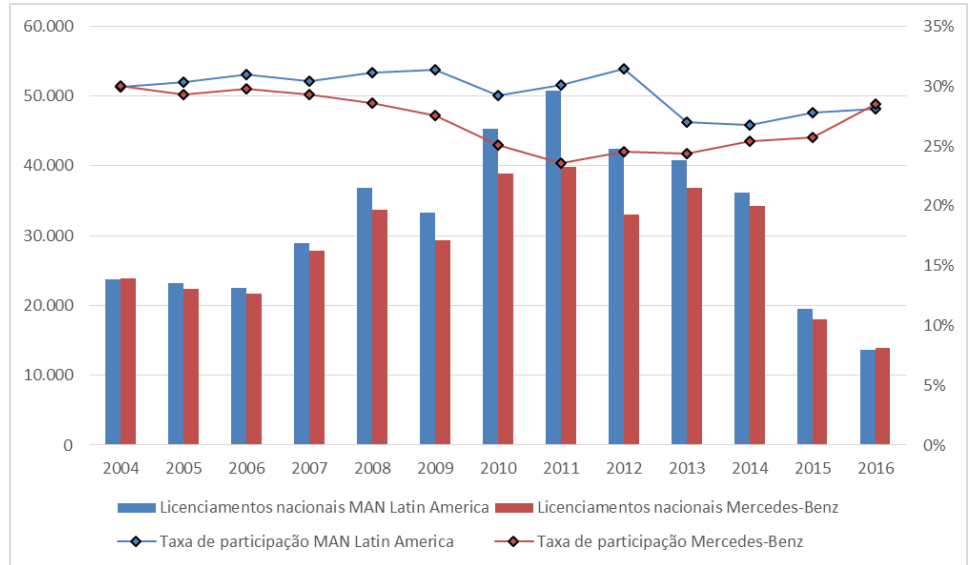

Fonte: o próprio autor, a partir dos dados da ANFAVEA (2017c). 


\section{Gráfico 2}

Quantidade de ÔNIBUS nacionais licenciados pela MAN Latin America e pela Mercedes-Benz e suas respectivas taxas de participação no total de licenciamentos

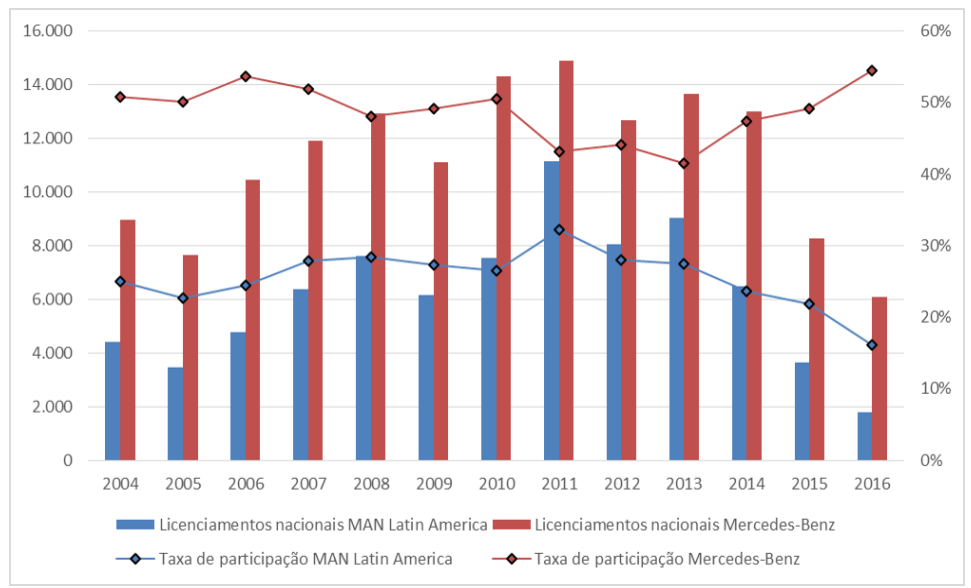

Fonte: o próprio autor, a partir dos dados da ANFAVEA (2017c).

\section{ESTRATÉGIA DE MERCADO: ESTRATÉGIA DUAL BRAND}

No que diz respeito a sua estratégia de mercado, a empresa passou por um processo de reposicionamento após a aquisição pela MAN SE. Estratégia de mercado pode ser definida como o conjunto dos "bens e serviços ofertados pela organização e sua estrutura de comercialização, remetendo ao modo pelo qual a corporação transnacional se posiciona diante de competidores nos mercados dos quais participa" (Ramalho; Santos, 2015, p. 8).

A partir da aquisição, a empresa decidiu por uma estratégia dual brand, que consiste em uma separação simbólica: a marca MAN Truck \& Bus foi posicionada no segmento premium, com produtos de acabamento mais refinado, e a marca Volkswagen Caminhões e Ônibus, na linha de produtos budget, vinculando seus produtos às ideias de durabilidade e flexibilidade tailor made. Nas palavras do entrevistado João Herrmann: 
A MAN Latin America era MAN e Volkswagen, então era um dual brand. Era uma estratégia dual brand. Não ia deixar de existir a Volkswagen por causa disso. Até porque a gente posicionou os produtos como MAN sendo premium e Volkswagen como sendo produto budget, mais barato e tal. Nosso conceito é "menos você não quer, mais você não precisa", tailor made e tal (Herrmann, 2016, p. 5).

Tal posicionamento também foi direcionado em consideração à relação com as concorrentes:

A gente tem esse posicionamento. A MAN está posicionada como premium, então ela pega as outras marcas premium, que seriam Volvo e Scania. E a Volkswagen posiciona-se como e está focada em Mercedes e Ford. É simples: você posiciona as marcas, você sabe onde elas estão e você decide onde você vai atacar (Herrmann, 2016, p. 7).

A respeito dessa separação simbólica, Herrmann faz uma analogia a partir de duas marcas do segmento de carros de passageiros, a Audi e a Volkswagen, ambas também pertencentes ao Grupo Volkswagen:

Então a marca MAN com a marca Volkswagen estariam associadas no mercado, mas com produtos distintos. Seria como se você colocasse em automóveis como se fosse a Audi e a Volks. Se você pega uma Audi A3 e um Golf os carros são praticamente o mesmo no nível de engenharia, de plataforma, mas sob o ponto de vista de marketing eles têm uma posição totalmente diferente. Você não vê um A3 quando você vê um Golf. Por mais que um engenheiro que tenha desenhado fale assim "Ah, esses dois carros são iguais por baixo". Só que vai falar para a sua esposa, que está ganhando um [carro], que ela vai ganhar um Golf ou que ela vai ganhar um Audi. O posicionamento de marca é que determina o valor. Então, a Audi tem um valor maior. Você tem mais refino no produto, você tem um acabamento um pouco mais detalhado, você tem alguns itens de tecnologia que você seleciona para deixar no premium e deixa o outro com menos (Herrmann, 2016, p. 6; destaque nosso).

Podemos observar como as marcas se localizam em uma espécie de "território imaginário" (Norberto, 2004, p. 204), buscando 
interpretar e participar dos processos de distinção social a partir da identificação dos anseios e símbolos mobilizados por um determinado agrupamento social e materializando-os em um bem ou serviço. Em outras palavras, ao mesmo tempo em que as marcas se alimentam dos processos de distinção e de constituição de identidades na sociedade, elas participam ativamente desses processos através da oferta de bens e serviços que materializam os desejos dos diferentes grupos sociais (Norberto, 2004, p. 210).

Ademais, com a aquisição da MAN SE, o Grupo Volkswagen optou, em 2015, por unificar todas as suas marcas de caminhões e ônibus em uma holding, a Volkswagen Truck \& Bus GmbH, com sede na cidade alemã de Braunschweig (Kutney, 2017). Fazem parte da holding as empresas MAN Truck \& Bus, Scania e MAN Latin America, esta última detentora da marca Volkswagen Caminhões e Ônibus (cf. Figura 1).

\section{Figura 1}

Fonte: MAN Latin America, 2016

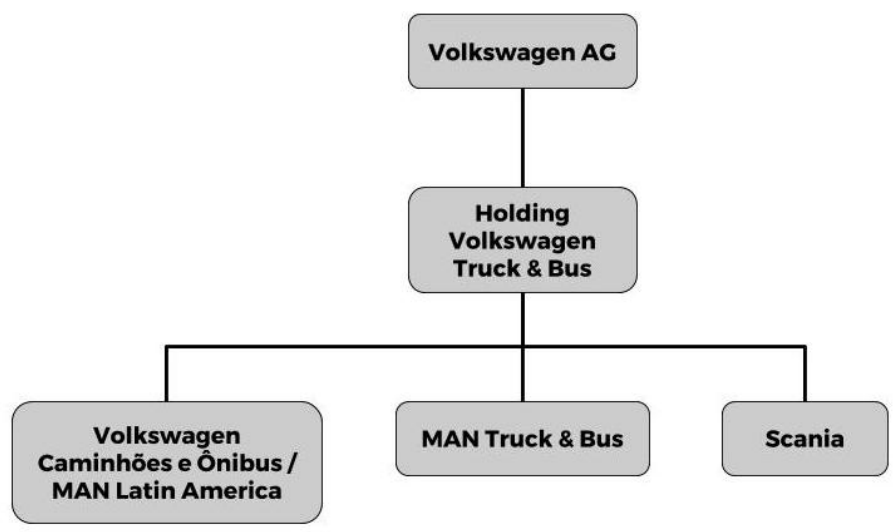

Fonte: o próprio autor, a partir de informações de Volkswagen AG (2015) e João Hermann (2016). 
Administrativamente, tanto a Volkswagen Truck \& Bus quanto a Volkswagen Nutzfahrzeuge respondem ao Membro para Veículos Comerciais do Conselho do Grupo Volkswagen, Andreas Renschler. Segundo ele, a unificação mantém a independência das marcas, acelera os processos de decisão e propicia mais foco nas necessidades do setor (Volkswagen AG, 2015).

Observa-se, portanto, que, a partir do momento em que as corporações consolidam de maneira bem-sucedida suas marcas, elas passam a deter um "ativo simbólico" (Norberto, 2004, p. 220) ou "ativos intangíveis" (Willmott, 2010, p. 519) e passam a extrair uma renda de marca (Henderson et al., 2011). As decisões de compra e fusão transparecem um tratamento de ativo.

\section{ESTRATÉGIA DE PRODUTO: O SETOR DE MARKETING}

Objetivo deste tópico é mapear as etapas de elaboração e de lançamento de um novo produto, nesse caso de um caminhão ou ônibus, atentando para o papel das marcas nesse processo. Para os objetivos deste trabalho, usaremos uma definição própria de estratégia de produto a partir do trabalho de Norberto (2004): o conjunto de metodologias e de recursos, inclusive tecnológicos, mobilizados para a concepção do produto. A esse respeito, trataremos mais detidamente do trabalho realizado pelos setores de marketing e de engenharia da MAN Latin America, pois são aqueles diretamente responsáveis pela estratégia de produto.

As linhas de produtos da MAN Latin America dividem-se entre aqueles da marca Volkswagen e aqueles da marca MAN propriamente dita. Os modelos de caminhões são divididos por categorias que, segundo classificação da ANFAVEA (2017b), são definidas pelo peso bruto total (PBT), medido por toneladas: caminhões leves até 10 toneladas, médios entre 10 e 15 toneladas, e pesados acima de 15 toneladas. Ademais, a MAN Latin America também define como extrapesados os modelos pesados maiores e de maior potência, medida por cavalos mecânicos.

A marca Volkswagen abrange os modelos de caminhões leves, com a linha Delivery; os modelos médios e pesados, com as li- 
nhas Worker e Constellation; e os extrapesados, também com a linha Constellation. Os produtos de marca MAN resumem-se basicamente aos caminhões TGX na categoria de extrapesados. Esses caminhões podem ser utilizados para transporte urbano, rural ou rodoviário de cimento (betoneiras), de veículos leves (cegonheiras), de grãos (graneleiros), de combustível, de bebidas, de alimentos refrigerados (frigoríficos), de troncos de árvore, de resíduos (compactadores ou basculantes), dentre outras possibilidades de carga.

Além disso, a MAN Latin America possui dezoito diferentes modelos da linha de ônibus Volksbus para os mais diversos usos, como transporte urbano, rural e rodoviário de passageiros e transporte escolar (Man Latin America, 2017b).

A gerência de Marketing da MAN Latin America, da qual João Herrmann é o responsável, se subdivide em três subáreas: Marketing de Produto; Inteligência de Mercado; e Mídia e Promoção. Herrmann descreve as atividades das subáreas da seguinte maneira:

Eu tenho a parte de Marketing do Produto, que é do que a gente vive aqui, que é fazer produto. A Volkswagen vive de vender caminhão, ônibus e peça. Então a área de Marketing do Produto faz toda a parte de especificação dos modelos, relacionamento com o cliente, com vendas, para fazer estudo de mercado e de tipos de veículos apropriados para aplicações, enfim... Passa isso para a engenharia, o requisito de mercado. E aí depois eu tenho a parte de Inteligência de Mercado, que faz toda a parte de monitoramento de volumes, análise de mercado em geral, com volumes e produção da concorrência, na medida do possível, na medida em que o compliance permite, porque hoje as regras estão mais travadas. A gente faz análise tanto de programação de produção quanto de equação de volumes futuros da indústria, enfim.... E a parte de Marketing mesmo que todo mundo conhece, que quando você fala de marketing acha que só faz isso e na verdade não é, que é a parte de mídia, promoção, eventos e relacionamento com o cliente, o famoso CRM, o Costumer Relationship Management. Então, basicamente, a minha área é composta por essas três subáreas, onde eu tenho aí em torno de 20 colaboradores. Já foram mais de 30 , hoje na crise a gente reduziu bastante (Herrmann, 2016, p. 1). 
O processo de lançamento de um novo caminhão ou ônibus começa na subárea de Marketing do Produto, que se alimenta de um grande conjunto de dados das ferramentas de Costumer Relantionship Management (CRM) e daquelas produzidas pela Inteligência de Mercado, como comparação da atuação da empresa com as concorrentes. O objetivo é identificar demandas existentes ainda não supridas pela empresa ou tendências de demandas que estão para existir.

Depois que o Marketing de Produto sistematiza as demandas existentes ou futuras por novos produtos ou qualidades, especificando seus motivos, envia essas informações para o setor de engenharia da MAN Latin America, que se encarrega de avaliar a viabilidade financeira e de traçar as guidelines ${ }^{3}$ de um novo produto. Essa concepção da engenharia então retorna ao Marketing de Produto, que avalia e pode propor alterações. Essas idas e vindas de um setor ao outro podem ocorrer algumas vezes até que ambas as partes cheguem a um consenso sobre o melhor projeto de produto. Nas palavras de Herrmann:

Quem está focado no desenvolvimento é o Marketing do Produto. Daí, com o pessoal de Inteligência de Mercado, eles têm ali toda a base de informação do mercado, ou seja, volumes, posicionamento de preço, benchmarking com produtos da concorrência. E com isso eles traçam, digamos assim, a origem dos business case que finanças e a parte da engenharia vão calcular para ver se aquele produto vai dar dinheiro para a empresa ou não. [...] O Marketing do Produto fala "Olha, existe uma demanda de mercado ou que já existe ou que ainda virá a existir". Então a gente tem que ajustar um produto hoje para um mercado que já existe e [para o qual] nós estamos defasados. E o porquê, tem que colocar lá os porquês e o que precisa fazer. $\mathrm{Ou}$ "Estamos vislumbrando aqui uma mudança de legislação ou de comportamento do cliente e nós precisamos daqui a três anos de um produto bem posicionado dessa forma". E eles escrevem tudo isso, documentam. E a engenharia pega e traça os guidelines do produto que isso seria. Lógico que eles voltam para a gente e a gente fala "Não, não é isso". O engenheiro tenta sempre fazer o caminho mais fácil, mais curto, mais barato e não necessariamente é isso o

3 Termo usado pelo Gerente de Marketing João Herrmann. Em tradução literal, linhas-guia, ou seja, os eixos norteadores, os parâmetros de condução de determinada tarefa ou, nesse caso, do novo produto. 
que o mercado quer. Normalmente, volta para cá e a gente fala "Não foi isso o que eu pedi, tem que mudar isso e isso" e acaba ficando em um meio termo (Herrmann, 2016, p. 9).

Em todo o processo de desenvolvimento de produtos, a engenharia possui uma autonomia para empreender pesquisas que resultam em aparatos tecnológicos que não necessariamente possuem demanda identificada pelo Marketing de Produto. Nesses casos, porém, cabe ao Marketing de Produto o papel de inteligência no sentido de analisar se essas inovações possuem mercado consumidor ou se não serão compreendidas. Esses casos, segundo Herrmann, são majoritários nas operações da empresa:

Na maioria das vezes, aquilo que surgiu como só uma ideia de produto você não necessariamente tem um mercado por trás. Então, a engenharia faz sim muita coisa pensando como inovação. E aí às vezes a gente pega aquilo ali e fala "pô, isso o mercado não vai entender, isso aqui está muito caro, isso aqui não precisa" ou "isso aqui demorou, eu estou atrasado, me dá aí” (Herrmann, 2016, p. 10).

Kátia Visentainer, entrevistada que atua com assessoria de imprensa no mercado automotivo, relata um processo muito semelhante para o caso de desenvolvimento de um carro de passageiros e reforça a importância das pesquisas de mercado. Segundo ela, pesquisas internas vão comparar o desempenho das vendas da empresa com as das concorrentes - atividade que, no caso de veículos de passageiros, será em algum setor análogo à Inteligência de Mercado descrito por Herrmann. Essas pesquisas seguem dois caminhos: a análise da linha de produtos da própria empresa com o objetivo de identificar deficiências e possibilidades de inserção em determinados nichos de mercado; e a análise dos modelos da concorrência, voltada ao desenvolvimento de modelos que ocupem possíveis vácuos deixados por esses modelos concorrentes. Nas palavras da entrevistada:

Nesse processo todo eu acho que a empresa faz pesquisas internas. E essas pesquisas começam do que? Elas fazem análise de concorrência. Então, por exemplo, isso até os veículos publicam. Quando 
você publica o carro do ano, ele é o carro que mais vendeu naquele ano, e então os próprios veículos já têm aquilo determinado: na faixa tal de preço, categoria tal, blablablá. A Quatro Rodas faz isso. [...] E aí, a montadora está vendo que aquele carro, que é um carro desenvolvido para um público $\mathrm{X}$, da concorrente, está batendo recorde de venda e o dela não está. E aí ela tem duas opções: ela pode lançar um novo modelo ou ela pode dar uma cara nova. [...] Você tem lá que naquele público você não está legal e tal. Você vai chamar essa agência de pesquisa que vai trabalhar com esse público; ela vai dar uma série de respostas. Na verdade, a agência de pesquisa vai trazer para a montadora nessa pesquisa, quando ela traça o perfil desse público, quais são os anseios desse público (Visentainer, 2016, p. 9).

Visentainer exemplifica a busca por identificação de novos nichos de mercado consumidor através de dois públicos distintos e suas respectivas demandas ainda não alcançadas por uma montadora hipotética: jovens até 30 anos, e homens de meia idade.

Em geral, a coisa começa no que? Você tem uma pesquisa e você vê lá tais carros que você tem na sua linha naquele país e que, com tais carros, você atende públicos $\mathrm{X}, \mathrm{Y}$ e $\mathrm{Z}$, mas, de repente, o público na faixa de 24 a 29 não é consumidor do teu carro. Aí começa toda uma pesquisa do que busca um consumidor de 24 a 29 anos, o poder aquisitivo que tem esse público, etc. Aí você decide através de pesquisa e tem algumas agências que trabalham só com esse tipo de pesquisa de consumidor de carro, os perfis e tal. E você entende que o cara de 24 a 29 anos tem poder aquisitivo para um carro que vai chegar lá na ponta por uns 35 mil reais, que ele quer um carro esportivo, que ele quer um carro com direção hidráulica, que ele quer um carro com determinadas características. [...] Quando você pega um público com mais de 50 anos consumidor de carro, por exemplo, ele tem a preocupação da segurança, ele tem a preocupação se os módulos de vidro elétrico são todos daqueles antiesmagamento, se tem determinados itens de segurança no carro, como é o freio, se o freio é de tal marca ou não... Já quando você pega um público mais jovem, ele não tem tanta dessa preocupação, ele vai ter a preocupação de um carro esportivo ou de um carro bonito, um carro com assentos de couro... Coisas que, para um cara mais velho, não necessariamente... (Visentainer, 2016, p. 2). 
O segundo caminho de pesquisa - a análise da concorrência e suas eventuais deficiências - é exemplificado com o caso real que resultou no lançamento do modelo Up! da Volkswagen. Segundo ela, a montadora identificou que um determinado carro da concorrente voltado ao público jovem tinha um preço maior do que o poder de compra desse grupo. Ao identificar esse vácuo deixado pela concorrente, a Volkswagen teria lançado o modelo Up! com qualidades semelhantes e menor preço.

Ou você tem, por exemplo, nessa pesquisa, meio o que foi o lançamento do Up! da Volkswagen, em que você tinha um carro de uma concorrente que as pessoas tinham muito interesse, mas que tinha um valor de mercado alto para o público naquela faixa etária. Então o que a Volkswagen faz? A Volkswagen faz o Up!, que é um carro tão moderno quanto o da concorrente, só que, na verdade, é um carro com custo muito mais barato (Visentainer, 2016, p. 3).

A respeito das metodologias utilizadas pelas agências de pesquisa, Visentainer menciona métodos qualitativos, como rodas de conversa com grupos de consumidores e até mesmo test drive com modelos de diversas marcas:

Quando começa a construção do lançamento dessa marca, da construção dessa marca, primeiro que você já tem, nesse caso, por exemplo, todo um trabalho de pesquisa de quem é teu público; você conhece o perfil do teu público muito a fundo. Porque nessas rodas de pesquisa, essas agências, além de fazer todo um estereótipo do que é o imaginário dessas pessoas sobre o que seria esse carro, ela tem rodas de conversa ao vivo, ela tem análise da concorrência, ela faz inclusive teste do tipo convidar determinado grupo para dirigir $\mathrm{X}$ carros de várias marcas e falar "olha o que eu gosto nesse, o que eu não gosto nesse". Então, quando ela chega para fazer um desenho, ela já tem uma pesquisa de qual é o perfil do teu público muito certinho (Visentainer, 2016, p. 3).

De maneira similar ao caminho relatado por Herrmann para o caso dos caminhões e ônibus, os desejos desse público consumidor alvo do novo carro de passageiros traçados pelas pesquisas são então enviados para o setor de engenharia da montadora, que é responsável 
por fazer o desenho do carro: "Quando ele [resultado da pesquisa] decide o que esse público consumidor quer, acho que entra a engenharia da própria empresa - isso ninguém terceiriza, que é a construção do desenho desse carro" (Visentainer, 2016, p. 3).

Apesar do desenho do carro ser de responsabilidade da engenharia da própria montadora, a partir das informações provindas do setor de marketing, o desenvolvimento tecnológico de peças, hoje, é feito majoritariamente pelas empresas de Original Equipment Manufacturer $(\mathrm{OEM})^{4}$. O tamanho da rede de produção aumenta o grau de complexidade de desenvolvimento de produtos:

Para você lançar um novo carro, o preço de projeto disso é uma coisa absurda. Se você imaginar um carro, construir um carro, você vai estar trabalhando com 80 fornecedores de peças. E quando você vai desenhar um carro, você tem que imaginar que você vai precisar de 80 pessoas desenhando novas peças para aquele carro ainda na fase de testes, quando está saindo o desenho (Visentainer, 2016, p. 2).

As entrevistas reunidas neste trabalho ratificam os trabalhos que apontam para a centralidade do marketing e das pesquisas de mercado, principalmente qualitativas, para a identificação de "tendências latentes na cultura" (Norberto, 2004, p. 206) ou de "desejos inconscientes" (Lury, 2004, p. 19) no processo de desenvolvimento de produtos. Ressalta-se que esses desejos não são individuais, mas pertencem a um grupo social, que maneja um conjunto de símbolos que compõem sua identidade e seu estilo de vida. O trabalho desses profissionais do marketing, em conjunto com os engenheiros, busca materializar esses desejos em características físicas de um produto.

Mas qual é exatamente o papel do branding na estratégia de produtos? Como argumenta Norberto (2004, p. 203), as marcas são signos que nos remetem a determinados conceitos ou valores. A imagem de marca constrói e é construída a partir de uma coerência entre esses conceitos/valores, as características físicas dos produtos e os desejos e imaginário dos consumidores, os quais se busca conquistar.

4 Original Equipment Manufacturer (OEM), em tradução literal, significa fabricante de equipamento original. A noção diz respeito às empresas que fabricam sistemas ou componentes de produtos finais pertencentes a uma outra empresa. No caso da indústria automotiva, tratam-se das empresas fornecedoras de autopeças. 
A marca de caminhões Volkswagen, por exemplo, nos remete à confiança, à adaptabilidade, à robustez, à noção de tailor made e à nacionalidade alemã, que, por sua vez, nos remete a rigor e a perfeccionismo. Nas palavras de Herrmann:

Hoje, nosso discurso é válido, que é: o Volkswagen é um produto tailor made, ou seja, ele é feito sob medida para o seu negócio. A gente tem o slogan que é "Menos você não quer, mais você não precisa", ou seja, é o sapato certo. Essa é nossa imagem. É um caminhão que vai bem em qualquer aplicação e que é robusto, tem as características que o mercado exige, então nem é tão sofisticado a ponto de ser sensível, é uma coisa que tem uma durabilidade muito grande; mas também não é muito espartano a ponto de matar o motorista de tão duro e difícil de dirigir. Então a gente é o sapato certo. Eu acho que o que definiria mesmo a gente é dizer que nós somos uma empresa tailor made. Vai lá, fala para mim o que você quer. Eu faço (Herrmann, 2016, p. 11).

A MAN Latin America, no sentido de dar coerência aos conceitos de sua marca, possui um grande leque de modelos com estrutura adaptável para múltiplas funções e construídos modularmente, de maneira coordenada a uma estratégia produtiva de consórcio modular:

Eu acho assim: quando um produto seu já nasce com essa filosofia, você já tem isso em seu design, você tem um produto pronto para ser adaptado para sua necessidade. Então, tanto a gente pode fazer um produto certinho para você, você fala "Olha, eu preciso de um produto para fazer isso". Eu faço ele certinho para você, então você não precisa comprar o caminhão e adaptar, fazer nada. Só que, mesmo que você compre um caminhão genérico nosso, você vai perceber que, precisando, ele é muito fácil de adaptar. Quem compra o meu Volkswagen genérico - que existe, que é o caminhão de estoque, está lá... Peguei [p. ex.] um 24.280, que tem $c a b$ com entre-eixo 5207. "Pô, mas eu vou usar uma 'bascu', vou usar um caminhão com basculante, então meu entre-eixo não é 5207, é 3560". O que eu faço? Eu vou lá e encurto o caminhão, coloco uma tomada de força para colocar a báscula, vou colocar um escapamento redirecionado para não fazer poeira... Não sei, vou fazer algumas modificações no caminhão. Você vai descobrir quando você for fazer isso num 
Volkswagen que ele é muito mais fácil que o da concorrência. Eu falo "Pô, Volkswagen eu só cortei aqui, emendei, peguei lá uma tomada de força, botei, já acionei, tinha um botão no painel lá e a báscula está funcionando". Aí o da concorrência: "Puta, descobri que se eu for cortar aqui eu não posso porque aí quebra ali...”. Entendeu? Então, quando você já nasce sabendo que seu produto tem que se adequar, ele já fica pronto para ser modificado, mesmo que não tenha saído de fábrica assim (Herrmann, 2016, p. 13).

O trabalho de design também é uma das maneiras de se construir essa coerência com relação às características físicas. No caso dos caminhões Volkswagen, por exemplo, somente pequenas alterações de estilo são realizadas pela engenharia na fábrica de Resende e as alterações mais significativas, que definem o produto, são centralizadas pela matriz alemã, conforme explica Herrmann:

Se é alguma coisa pequena, uma alteração de cor, um adesivo, um nome, uma coisa assim a gente faz aqui na engenharia. Eles têm lá uma pessoa de estilo que faz esses estudos. Agora, se é realmente uma alteração de design mesmo como um novo guide line da marca, aí é tudo na Alemanha. Isso sempre foi assim. Isso não mudou. Mesmo quando a gente era só Volkswagen lá em 1981 você tinha que mandar para lá e o pessoal de estilo da Alemanha falava "Olha, tem que ser mais ou menos assim e tal" e a gente trabalha naquelas guias. Eles têm guias de marca (Herrmann, 2016, p. 10).

\section{ESTRATÉGIA COMUNICACIONAL}

Estabelecido o consenso sobre o que será o novo lançamento da empresa, o passo seguinte é enviar as informações para a subárea de Mídia, Promoção e Evento (cf. Figura 2), que tratará de traçar as estratégias adequadas de comunicação. Nesse sentido, essa subárea, como Herrmann diz, é uma espécie de cliente do Marketing de Produto:

Mas a parte de publicidade, mídia, isso aí pouco afeta [no processo de desenvolvimento]. Na verdade, eles [a subárea de Mídia, Promoção e Evento] são clientes do que o [Marketing de] Produto faz. Fez um produto novo, bolou um produto novo, com informações do 
mercado e tudo, passou para a engenharia e depois fez. Mídia, Promoção e Evento vai pegar isso aqui e daí vai pensar assim: "Bom, o que nós vamos fazer agora para divulgar esse produto, balançar? Onde nós vamos participar? Em que mídia nós vamos entrar? Qual evento a gente vai fazer?" (Herrmann, 2016, p. 9).

\section{Figura 2}

Ilustração da rede de produção de caminhões e ônibus MAN Latin America

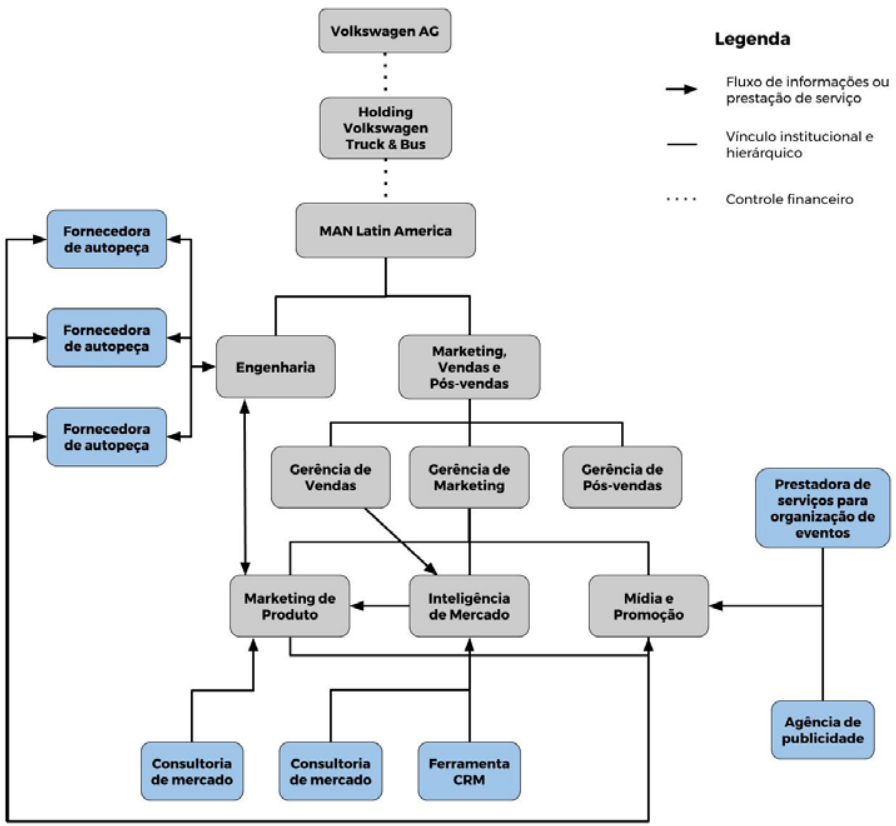

Fonte: o próprio autor, a partir das informações de Herrmann (2016) e Visentainer (2016).

Diferentemente das outras atividades do setor de marketing, nas quais há algumas contratações de prestadores de serviços, Herrmann admite que o trabalho do subsetor de Mídia e Promoção é praticamente todo terceirizado, cabendo à MAN Latin America solicitar mudanças e tomar decisões com base nas opções apresentadas pelas agências. 
Olha, até por uma questão de auditoria, de compliance, a gente necessariamente precisa da agência para coordenar todas as suas ações que você faz no campo. Então, por exemplo, eu nunca contrato uma empresa de filmes para fazer um vídeo. Eu não contrato, quem contrata é sempre a agência. Por quê? Para não dar problema de quem vai pagar o que. Então a agência é nosso advogado, ela está ali na linha de frente e ela faz tudo o que a gente não conseguiria fazer. Hoje, toda a operação nossa de mídia e publicidade é a agência. $\mathrm{O}$ resto, que faz parte de evento e CRM a gente também utiliza de outras agências menores, que não essa maior, mas aí a nossa inteligência é muito mais aqui dentro. [...] Então a ferramenta do CRM hoje é quase proprietária. Ela só não é $100 \%$ porque, hoje, com essas questões de big data de informações, eu não vou conseguir ter um servidor de big data aqui para eu gerenciar o meu CRM e fazer frente com um do banco. Não dá. Não vou competir com uma Google da vida. Não vou. Então, hoje a gente contrata empresas que fazem isso. Só que o centro nervoso, as pessoas que tem a cabeça pensante aqui nos projetos de CRM, estão aqui dentro. Essas questões mais estratégicas e de relacionamento estão com a gente, só que as ferramentas não são nossas. As questões mais táticas e de produção de material, vídeos, e não sei o que, e publicidade em geral é quase $100 \%$ agência. A gente fica aqui muito mais na parte de decisão sobre as propostas que eles trazem. E menos na produção. Eles fazem toda a parte de produção e a gente fica na aprovação. A gente fala "Olha, legal, gostei disso, vai por aqui, vai para outro, não muda isso aqui, faz assim...." Essa parte é muito mais terceirizada. A outra não. A parte de evento e de CRM é toda feita aqui, só que a gente usa a mão de obra de prestadora de serviço para fazer essa parte mais de informação e de operação de eventos (Herrmann, 2016, p. 8).

O trabalho da agência de publicidade, segundo Visentainer, parte das atividades já realizadas de mapeamento dos desejos do público-alvo. O objetivo explícito é convencer o cliente potencial que o produto desenvolvido atende a seus desejos:

Mas quem vai criar, na verdade, toda essa comunicação de como você transforma... Como posso te dizer? Eu fico sabendo os desejos dessa galera, mas quem vai trazer toda o que seria a sedução para essa galera é a agência de publicidade da construção dessa marca. 
Eu acho que são duas linhas: baseada nessa pesquisa, a montadora vai montar o carro, vai desenhar esse carro, esse modelo, baseada no que esse público deseja. Mas aí eu acho que tem uma terceira questão, que é: como eu conto para você que o que você deseja é exatamente esse carro. E aí eu acho que entra a agência de publicidade (Visentainer, 2016, p. 9).

A própria escolha da agência de publicidade vai depender do público consumidor que a empresa quer alcançar, considerando a natureza especializada do mercado de publicidade e sua segmentação por públicos específicos:

Para você ter uma noção da grandiosidade do investimento que é feito nisso, imagina você que não existe uma agência publicidade para cada montadora; as montadoras, no geral, trabalham com mais de uma agência. Por exemplo, ela tem a primeira pesquisa e esse público do Up! é um público jovem, ela vai procurar uma agência que tem uma cara, uma linguagem de comunicação mais para esse estilo e a Volkswagen vai ser cliente dessa agência com esse carro (Visentainer, 2016, p. 4).

Ainda segundo Visentainer, o trabalho da agência de publicidade envolve uma questão sensorial, chegando ao ponto de ser quase um estudo psicológico:

Então você vai entrar muito na questão do sensorial, porque o lançamento de uma marca tem isso. O Up!, quando ele foi lançado seguindo a minha própria história do Up!, para ficar mais fácil primeiro que ele era lançado em cores que não tinha no mercado e cores extremamente jovens, eles tinham um comercial em que o carro mudava de cores, em que o cara estava na balada... Então, assim, ele trouxe aspectos da vida de quem era esse público para quem esse carro estava sendo lançado para toda a sua comunicação. [...] E aí entra a agência de publicidade que vai criar todos esses anúncios, essa identidade visual do que vai ser o lançamento. Vai ser o pessoal de criação de uma agência de publicidade que trabalha para a montadora. [...] E aí essa agência vai fazer o que? Ela vai fazer todo o trabalho de criação de identidade visual dessa marca e que aí já tem tudo a ver com uma pesquisa... Eu não trabalho 
necessariamente com isso, tá? Mas tem todo um estudo - eu brinco que é quase um estudo psicológico - e, por exemplo, dizem que as cores amarelo e vermelho são as cores que te dão fome e por isso que o McDonald's, por exemplo, a logo deles é amarelo e vermelho. Então você tem desde questões do que cada cor te motiva, o pantone dessas cores todas na criação dessa identidade visual; o que é esse desejo de modernidade, de formas, de sensualidade; tem a ver com as formas com as quais você vai criar essa campanha e tal. E aí essa agência cria essa primeira publicidade, que seria o lançamento do carro. Aí é nessa fase que entra a parte de comunicação. De que forma? Eu acho que, primeiro, é no trabalho acompanhando todo o material fotográfico que é feito desse carro, mas, na verdade, quem tem o comando desse trabalho não é agência de comunicação, é a agência de publicidade, porque é quem cuida, digamos assim, de toda as questões da marca enquanto design visual e tal. Aí, baseado nisso, você vai contar a história desse carro, que é o que? A agência lapidou e a coisa já chega para você meio encaminhada e você vai dar a cara que precisa para isso. (Visentainer, 2016, p. 4-5).

Nesta fase do ciclo de lançamento de um novo produto, o esforço é produzir uma comunicação que dialogue adequadamente com os símbolos daquele grupo social que se busca conquistar enquanto consumidores. A associação entre essa comunicação e as características físicas do produto tem por objetivo demonstrar que seu produto é ainda mais útil do que o das concorrentes (Norberto, 2004, p. 6).

O trabalho da agência de publicidade, porém, não compreende todas as complexas atividades envolvidas no lançamento de uma marca. Visentainer comenta, por exemplo, o trabalho junto às concessionárias e às mídias especializadas, como a revista Quatro Rodas, que escrevem matérias de avaliação do produto:

Aí eu acho que vem a parte de comunicação mesmo, que envolve $\mathrm{N}$ pontos. Acho que envolve a comunicação no ponto de venda, que é, antes do carro ser lançado, todas as concessionárias da marca terem o modelo do carro para que as pessoas poderem conhecer, fazer o test drive e tudo mais. Acho que vem a questão para a mídia especializada. Ainda conta muito para o público do setor automotivo, de repente, o carro que você está lançando ter sido avaliado, por exemplo, por uma revista Quatro Rodas, o jornalista ter usado o carro, ter 
falado do carro. E tem a eleição dos carros do ano por esses veículos e tal. E aí eu acho que você começa um grande bloco de comunicação, que é o que? Tem a questão do lançamento da marca, então toda a comunicação vai ser feita com base naquele perfil daquele público, desde material de divulgação para ponto de venda, material divulgação em veículos, em geral pagos com folders de jornais, com páginas entre jornal e tal (Visentainer, 2016, p. 4).

A respeito das diferenças entre os processos de desenvolvimento de produtos dos segmentos de carros de passeio e de caminhões e ônibus, a entrevistada analisa que ambos são muito similares, ainda que o último seja mais simples. Considerando o uso dos caminhões e ônibus em processos produtivos, as pesquisas de mercado são realizadas principalmente com empresas de transportes e nelas destacam-se as demandas por características mais objetivas, como segurança e resistência, em comparação com o segmento dos carros.

Eu acho que o caminhão é mais simplista. É porque, na verdade, a montadora não fabrica a carroceria, né? A montadora fabrica aquele primeiro módulo do caminhão. Eu acho que, na verdade, é a questão de resistência, esse tipo de coisa. Eu acho que o processo talvez seja muito parecido, mas com pontos diferentes. Porque, na verdade, quando você vai comprar caminhão, você não vai comprar esse caminhão porque você vai se sentir poderoso, porque ele combina mais com você... Eu acho que as questões que são relevantes devem ser em termos de suporte, de segurança, e não necessariamente da mesma forma que você pensa em um carro. Mas eu acho que passa pelo mesmo processo. Eu acho que caminhão é mais simplista, primeiro porque você não tem tanta concorrência de tantos modelos, você não tem preocupação de todo ano lançar um modelo novo. Tanto que, quando você pega os caminhões da Mercedes Benz, acho que tem uns 50 anos que eles lançam os mesmos caminhões, não tem grandes inovações. [...] O grande consumidor, que vai comprar 10 ou 15 caminhões de você, é a empresa de transporte. Então, eu acho que talvez toda essa pesquisa seja sobre as necessidades que as pessoas têm. Então, se você pensar em termos de novas regras e tal, você pensar de repente "Ah, eles estão estão carregando", sei lá... . Agora as pessoas querem trabalhar com dois motoristas juntos fazendo as viagens, então ela quer levar o dobro de carga, então 
esse caminhão aguenta ou não aguenta. Eu acho que é nesse sentido (Visentainer, 2016, p. 22).

Além disso, segundo Visentainer, a comunicação para o segmento de caminhões e ônibus é mais direcionada, com menos peças publicitárias:

[...] se você olhar, não tem publicidade, não tem toda essa comunicação com caminhão. Porque eu acho que você já vai fazer uma divulgação mais específica. Eu acho que é meio como a gente pensa quando a gente fala em divulgação de peças para concessionária: você não envolve mídia, você vai envolver exatamente qual a expectativa daquela concessionária para que ela faça a venda daquela peça. Então é um marketing muito mais direto para ponto de venda e tudo mais, e eu acho no caso do caminhão deve ser dirigido nesse sentido. Você vai investir muito mais em feiras onde esse público que é o consumidor de caminhão vai estar, em pontos de vendas do que necessariamente em uma publicidade (Visentainer, 2016, p. 22).

As informações precisas sobre o perfil de consumidores de caminhão e o tipo de comunicação a eles direcionados não são disponibilizadas pelas montadoras. Porém, Boaventura (2011) nos apresenta uma interessante amostra construída a partir de um survey realizado com 94 clientes de uma determinada concessionária de Belo Horizonte em 2011. Os dados a respeito do processo de compra dos caminhões ratificam a opinião de Visentainer. Constata-se, por exemplo, que a principal fonte de comunicação é, com distância, a visita do vendedor da concessionária (40\%), com algum destaque para internet (18\%), jornal (14\%) e feiras especializadas (14\%) (cf. Gráfico 3). Como esperado, os principais fatores apontados que influenciam na compra são o conceito da marca (26\%), o preço do novo caminhão (26\%) e a marca que o caminhão possui (20\%) (cf. Gráfico 4). Por fim, ao analisar os fatores responsáveis pela preferência de marca, as principais características apontadas foram: durabilidade (15\%), consumo de combustível (14\%), preço de manutenção (13\%), desempenho (12\%) e facilidade de manutenção (12\%) (cf. Gráfico 5). 
Marcas e divisão de trabalho na rede de produção automobilística: o caso MAN Latin America.

\section{Gráfico 3}

Fonte de comunicação de maior importância para uma amostra de consumidores de caminhão

\section{Comunicação}

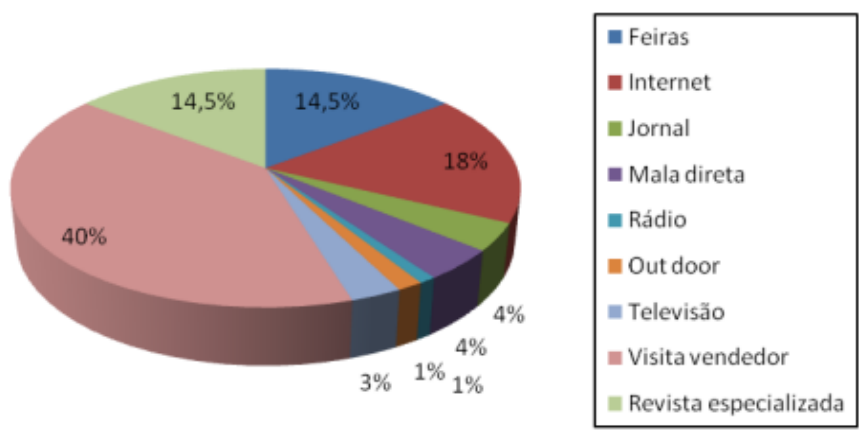

Fonte: Boaventura (2011, p. 62).

Gráfico 4

Fatores considerados na compra de uma amostra de consumidores de caminhão

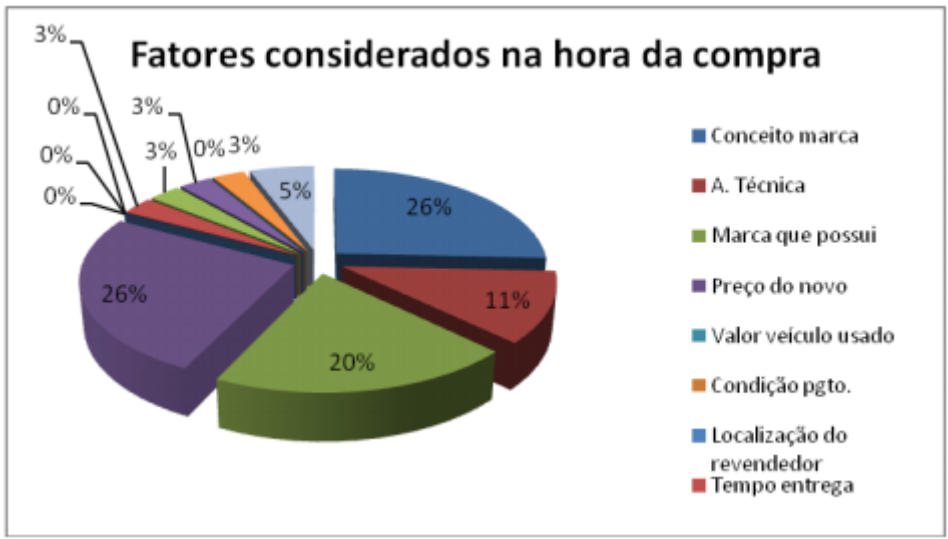

Fonte: Boaventura (2011, p. 62). 


\section{Gráfico 5}

Fatores considerados sobre a marca de preferência de uma amostra de consumidores de caminhão

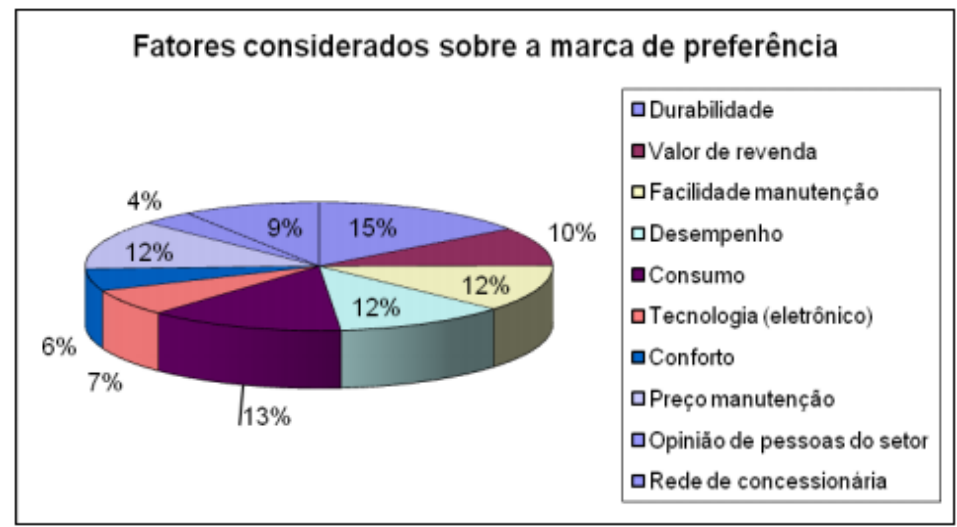

Fonte: Boaventura (2011, p. 62).

A respeito da coerência exigida entre os conceitos da marca e as estratégias de comunicação, Visentainer faz uma comparação entre as indústrias automobilística e de cosméticos:

Eu acho que tem todo um conceito - e é uma construção totalmente psicológica - do que você vende de ideia para o outro. E eu acho que quando você trabalha com beleza isso é muito gritante. [...] Quando você vende um produto, [por exemplo] um creme anti aging, você não está vendendo um produto para atenuar ruga daquela mulher; você está vendendo a ideia da juventude. Então, você tem um marketing perfeito quando a pessoa entende, por exemplo, que está comprando aquilo e está se sentindo mais jovem por estar comprando aquele produto que não necessariamente vai diminuir a ruga que ela tem, não necessariamente vai parecer que ela está mais jovem porque está com aquele creme na cara. Mas pela ideia de que ela vai se sentir mais jovem ela vira consumidora. E na questão do carro tem muito isso. Primeiro que as propagandas brasileiras ainda são muito voltadas para o público masculino. Eu não tenho pesquisa disso, dados numéricos para te dar, mas a ideia que se tem é de que homens ainda compram muito mais carros do que mulheres no Bra- 
sil. E, se você pensar, toda a propaganda do carro tem essa questão da autoestima do cara. O cara que está comprando um carro que tem um poder. Então, acho que quando você leva em conta como se comunicar com esse consumidor, acho que você tem toda uma criação de marketing baseada nos anseios que aquele cara tem, entendeu? Então é um cara que vai trocar de carro e de repente é um cara que, sei lá, não faz sucesso com as mulheres, é um cara que se acha meio infeliz. Então, de repente, você vende uma propaganda onde o cara está naquele carro, está com uma mulher maravilhosa do lado. Ele [o carro] representa um poder. Muitas vezes não é o banco que você tem no carro, ou o design da frente ou da traseira do carro, ou a cor que você disponibiliza para aquele carro, mas a ideia de que ter aquele carro vai mudar a sua vida - que não muda nada, o cara que não 'pega' mulher vai continuar não 'pegando' mulher com outro carro (Visentainer, 2016, p. 7-8).

No segmento de caminhões e ônibus, porém, como já foi dito, a entrevistada destaca que há menos peças publicitárias do que no segmento de carros de passageiros, e há uma atenção mais detida para outros métodos de divulgação direcionada, como participação em feiras de caminhõe.

Além da comunicação do produto, a estratégia comunicacional também implica na comunicação institucional direta. Visentainer acredita que o posicionamento da marca corporativa no mercado é tão importante na indústria automotiva que a maior parte do investimento em publicidade das montadoras é alocado nesses comerciais institucionais, que não focam em produtos específicos:

Mas eu acho que as montadoras têm todo esse trabalho principalmente na sua marca. Você pode medir muito isso. Se você de repente conseguir com alguém de alguma agência o plano de mídia de alguma montadora, você vai ver que, de todos os comerciais que ela faz, ela divide a coisa: estou chutando, não tenho números, mas vamos supor que ela invista $100 \%$ de dinheiro em publicidade de $\mathrm{TV}$, que é a grande publicidade do mercado automotivo - você não lança um carro sem anúncio de TV, sem comunicação de massa - eu diria que $40 \%$ dessa verba publicitária do ano ela investe na marca institucional, que é grifando o nome dela; e os outros $60 \%$ ela vai distribuir entre o que ela está lançando naquele ano (Visentainer, 
2016, p. 12).

A entrevistada também aponta que o investimento em publicidade institucional da Volkswagen aumentou como modo de reação à perda de participação no mercado 5 de veículos de passageiros. Em algumas peças publicitárias, segundo ela, a empresa fez questão de reforçar sua origem alemã e os atributos associados à nacionalidade ${ }^{6}$ :

E eu acho que tem duas diferenças que são fundamentais nisso tudo. Uma é como você constrói, consolida cada dia mais, quando você vai entrando em um mercado cada dia mais competitivo, a marca da sua empresa. Então na marca da sua empresa você vai consolidar o que? Você vai ter desde a consolidação de segurança, de tecnologia, de nome do país que representa... Hoje a gente tem dois grandes mercados do setor automotivo, que é a Alemanha e os Estados Unidos. Então, eles vão estar se posicionando muito em função disso - um porque inventou o carro e o outro porque necessariamente sempre teve a melhor tecnologia e tal - e vão agregar valores nisso. Então você vai ter, por exemplo: não sei se você acompanha propaganda, mas há alguns anos atrás, quando a Volkswagen começou a perder mercado no Brasil, ela entrou com comerciais institucionais de marca mesmo, não de um carro, um modelo específico, mas a sua marca, botou o presidente para falar da marca, e era um cara que era alemão, que falava um português todo atrapalhado e tal. E, embora a gente de comunicação, se olhasse, falasse "Ai, eu pensaria duas vezes antes de colocar um cara que fala um português super errado" existe a questão de mostrar ainda para o brasileiro que: "Somos alemães, então fazemos o melhor carro". E deu uma resposta muito boa para eles (Visentainer, 2016, p. 2).

5 A entrevistada não especifica o período histórico em que teria ocorrido essa perda de participação de mercado, mas os dados da ANFAVEA (2017c) apontam que a Volkswagen do Brasil foi responsável por aproximadamente $20 \%$ dos licenciamentos nacionais dos carros de passageiros entre 2003 e 2012, e, partir de 2013, essa porcentagem foi caindo continuamente até atingir $9 \%$ em 2016.

6 Não conseguimos localizar a peça publicitária mencionada pela entrevistada na qual há a participação do presidente da Volkswagen. Porém, é possível localizar no site Youtube, por exemplo, uma série de comerciais da campanha publicitária "É carro mesmo", da segunda metade da década de 2000 , nos quais um engenheiro falando em português com sotaque alemão ressalta características dos carros da empresa, associando-as a qualidades atribuídas ao povo alemão, como rigor e perfeccionismo. Também foram localizados alguns outros comerciais dos anos 2010 - década em que se observa perda de market share da montadora - que reforçam a nacionalidade da marca. 


\section{ESTRATÉGIA PRODUTIVA: O CONSÓRCIO MODULAR}

A fábrica de Resende foi construída a partir do modelo de consórcio modular, no qual os processos de montagem de caminhões e ônibus, assim como os custos irrecuperáveis com a construção da unidade, foram divididos entre fornecedoras de autopeças de primeira camada (Abreu; Beynon; Ramalho, 2006). Nesse modelo produtivo, as fornecedoras não somente fabricam os módulos como também participam diretamente do processo de sua montagem nos veículos.

São sete as fornecedoras que compõem a unidade de Resende, que fornecem respectivamente: chassi (Maxion), eixo e suspensão (Arvin Meritor), pneus e rodas (Remon), motor (Power Train, joint venture entre MWM e Cummins), armação de cabine (AKC Aethra), pintura (Carese), acabamento de cabine (Continental) (cf. Figura 3). A MAN/ Volkswagen fica "de fora do processo direto de produção, voltando suas atividades para funções estratégicas, tais como o design e a arquitetura dos veículos, assim como a qualidade, as políticas do produto, o marketing e as vendas" (Abreu; Beynon; Ramalho, 2006, p. 74).

Figura 3 - Composição do Consórcio Modular de Resende

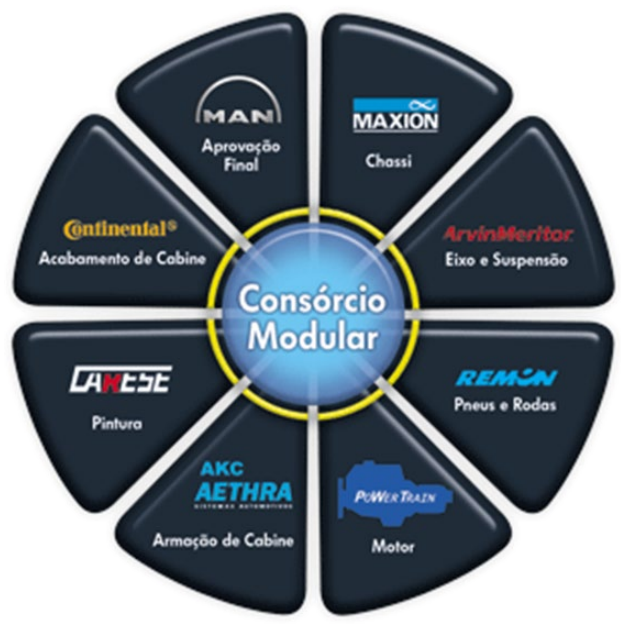

Fonte: MAN Latin America (2016). 
O modelo de consórcio modular constitui, portanto, um "rompimento completo e radical com tudo o que foi feito antes" (Abreu; Beynon; Ramalho, 2006, p. 73) no que respeita à organização produtiva no setor automotivo. O consórcio modular se diferencia até mesmo das plantas mais modernas da indústria automotiva brasileira, construídas em modelo de condomínios industriais, nos quais as fornecedoras foram levadas para o entorno da montadora com o objetivo de reduzir custos de transporte, ajustar a integração e prover o fornecimento de peças just in time (Abreu; Beynon; Ramalho, 2006, p. 73). Nessas plantas, as fornecedoras fabricam as peças e as entregam à montadora, que é responsável pela montagem final do veículo. Já em Resende, a linha de montagem é dividida entre as fornecedoras, que, além de fabricar as peças, coordenam sua entrega e as montam a cada etapa do processo produtivo. Na prática, os caminhões e os ônibus que recebem o escudo MAN ou Volkswagen são fabricados por empresas fornecedoras de autopeças.

Marco Saltini reforça a especificidade do consórcio em relação às outras experiências:

Mas quem é o funcionário que monta na linha? Na Ford, é Ford; na GM, é GM; e, na Volkswagen Taubaté, é Volkswagen. Quem é o funcionário que monta na linha na MAN? É Meritor, é Maxion, é Continental. Não tenho nenhum funcionário lá (Saltini, 2016, p. 28).

Trata-se de um nível "mais radical de horizontalização das relações interfirmas" (Francisco, 2005, p. 100), no qual as empresas do consórcio dividem o mesmo espaço, estabelecem uma política mínima comum de recursos humanos, tomam decisões coletivas e partilham custos, investimentos e riscos. Como menciona Marco Saltini, os trabalhadores das fornecedoras trabalham lado a lado, vestem o mesmo uniforme (que se diferencia somente pela logomarca da empresa estampada), almoçam no mesmo restaurante, são transportados da mesma maneira e possuem os mesmos salários e benefícios. Em suas palavras: 
[...] você não consegue colocar dentro do mesmo teto - que é o que a gente tem de fato e não há nas outras montadoras - pessoas de empresas diferentes com condições diferentes. Por quê? Um operador de produção da Maxion ganha o mesmo salário de um operador de produção da Meritor, porque eles estão no mesmo teto. E a gente diz o seguinte: a divisão de uma empresa para outra é uma linha pintada no chão. Quando tem a linha, porque agora já até apagou a linha. Os caras passam por cima, né. Se você não pintar de novo não tem a linha, então você só sabe onde estão os módulos, porque você sabe onde são os módulos. Mas você imagina o seguinte: eu sou operador de produção, o Rafael também, eu trabalho na Maxion e ele trabalha na Meritor, ele ganha dez reais por hora, eu ganho oito. Então vou falar: "Eu pego o mesmo ônibus do Rafael, venho do mesmo lugar, a gente almoça no mesmo lugar, ele trabalha a 15 metros de distância de mim, eu quero trabalhar lá, pô. Ele ganha dez lá, eu ganho oito por hora. Eu quero ir lá". Então, tudo dentro da empresa é igual, os salários são iguais, os benefícios... Inclusive com a MAN. Ah, não é que o cara da MAN... Não, o benefício é igual, tudo é igual. É só assim que você consegue fazer (Saltini, 2016, p. 30).

Apesar do discurso oficial de plena igualdade, Abreu et al. (2006) e Francisco (2005) apontam diferenças internas à fábrica de Resende e de suas condições e relações de trabalho comparadas a operações em outras regiões do país.

Em primeiro lugar, em entrevistas, trabalhadores mencionaram que a diferença entre as culturas empresariais gera discrepâncias, como o fato da MAN/Volkswagen ser mais hesitante para efetuar demissões do que as fornecedoras (Francisco, 2005, p. 104). Além disso, a política de igualdade salarial entre os trabalhadores das oito empresas do consórcio não abrange os trabalhadores de empresas terceirizadas, isto é, fornecedoras de camadas inferiores. Para esses últimos, busca-se apenas a garantia do mínimo exigido por lei (Francisco, 2005, p. 103).

Em segundo lugar, os dirigentes sindicais observaram diferença salarial significativa entre Resende e outras regiões onde o grupo Volkswagen opera: 
[...] em 1999, as duas maiores centrais sindicais do país (CUT e Força Sindical) unificaram forças para chamar atenção para o fato de que enquanto os níveis salariais no $\mathrm{ABC}$ eram de $\mathrm{R} \$ 1500,00$, os da Fiat em Minas Gerais eram R \$ 800,00 e em Resende, R \$600,00 (Abreu; Beynon; Ramalho, 2006, p. 82).

A questão dos salários de Resende foi inclusive um dos elementos decisivos para a escolha da Volkswagen por construir a fábrica na região. Premida diante da elevação de custos no $\mathrm{ABC}$ paulista e das pressões relacionadas à abertura comercial dos anos 1990, a Volkswagen buscou implementar a nova fábrica já sob um paradigma enxuto. Desse modo, os baixos custos com qualificação e a manutenção de níveis salariais e de benefícios comparativamente reduzidos são exaltados como vantagem competitiva pela gerência da empresa:

Quando a Volks veio para cá com um grande potencial de crescimento, com uma facilidade logística de você ter possibilidade de criar uma mão de obra capaz de ser treinada, com um custo muito menor do que se tinha na época. Eu não faço nem a comparação com Resende, eu faço comparação de quanto ganha um operador de produção na Volks em São Bernardo do Campo, e quanto ganha esse mesmo operador de produção em São Carlos, onde é a fábrica de motores. Quer dizer, é gritante, praticamente $40 \%$ do valor de mão de obra do outro, então, com uma chance de potencial grande. Ontem eu estava conversando - eu sou um dos presidentes da ANFAVEA também, e a gente teve a coletiva de imprensa para falar dos números de maio. E ontem eu conversava com uns colegas enquanto a gente preparava o material para apresentar, de outras montadoras. A gente falava, por exemplo, de um recém PLR que a Volvo deu de 30 mil reais. Quer dizer coisas assim absurdas. O PLR nosso só não é menor que o PLR acho que da Nissan, que foi um pouquinho menor que o nosso, que é 5 mil reais. Se você comparar com o meu maior concorrente, que é a Mercedes, o PLR deles foi 14 mil reais. Então você fala assim a diferença de valores da mão de obra é muito gritante. Então, eu diria: era uma região com um potencial de desenvolvimento, com determinadas facilidades que permitia instalação e a prova disso foi que efetivamente ela foi uma região que se desenvolveu muito (Saltini, 2016, p. 2). 
Ramalho e Santana (2002) observam que a região do Sul Fluminense pode ser compreendida, do ponto de vista da indústria automotiva, como uma região greenfield, isto é, um local de fácil acesso aos mercados consumidores, com uma infraestrutura mínima necessária, com uma mão de obra minimamente qualificada e com pouca tradição sindical. De fato, ao contrário da região do $\mathrm{ABC}$ paulista, na qual os trabalhadores do setor possuem décadas de experiência sindical junto à Central Única dos Trabalhadores (CUT), os trabalhadores das montadoras da região do Sul Fluminense são vinculados ao Sindicato dos Metalúrgicos do Sul Fluminense (SINDMETALSF), que compõe a central Força Sindical e que não possuía experiência de atuação no setor automotivo (Ramalho; Santana, 2002).

Porém, como bem aponta Rodrigo Santos (2006), sob outros aspectos, se considerarmos que o município de Volta Redonda se desenvolveu em boa medida em função da presença da Companhia Siderúrgica Nacional (CSN), a região do entorno poderia ser considerada um brownfield, isto é, uma região industrial antiga e decadente. Tendo isso em vista, pode-se dizer que a região de instalação do consórcio modular de Resende se caracteriza por ser um greenfield atípico (Santos, 2006, p. 130).

O grau de horizontalidade do consórcio modular também proporciona uma dificuldade do ponto de vista da gerência da MAN Latin America: ela é apenas uma das oito empresas do consórcio e, portanto, tem menos liberdade e poder de decisão (Francisco, 2005, p. 118). Saltini aborda essa questão ao avaliar que o modelo do consórcio modular não apresenta os mesmos benefícios, previamente indicados, em um contexto de retração econômica, pois a relação de parceria entre Volkswagen e fornecedoras de primeira camada gera uma demanda constante por negociações no que diz respeito às compras e vendas:

Nesse momento que o mercado está muito retraído, o consórcio não é tão bom. Porque cada um tem o seu investimento lá, quer melhorar e agora é um momento de baixa. Então você tem que negociar muito, e ele é o meu parceiro, então quando ele fala assim "Não, não eu não vou vender para você". "Bom, você não vende, eu não vendo o caminhão, você não remunera o seu investimento” (Saltini, 2016, p. 27). 
Apesar de todos os problemas, o modelo de consórcio modular parece valer a pena, mesmo em um cenário de retração. Os investimentos e os riscos envolvidos, bem como os custos correntes da fábrica são repartidos com as parceiras. A Volkswagen não paga as fornecedoras por caminhões e ônibus produzidos, e sim por caminhões e ônibus vendidos. Em outras palavras, a empresa só paga pelos componentes utilizados na fabricação de um caminhão quando este já foi efetivamente vendido, isentando-a "de muitos dos problemas financeiros associados ao estoque" (Abreu; Beynon; Ramalho, 2006, p. 75).

Outro aspecto ressaltado por Saltini é a baixa necessidade de força de trabalho, considerando a característica enxuta de sua organização:

Nós trabalhamos num sistema de um consórcio modular, portanto, a mão de obra empregada na minha produção é baixa, comparativamente. O consórcio modular, hoje, tem 3 mil e poucos [trabalhadores]. Nós chegamos a 7 mil no auge nosso, a 7 mil. Hoje eu tenho 3 mil e 200 pessoas. Dentro do consórcio todo. Se eu comparar isso com a Mercedes Benz, que produz a mesma coisa que eu produzo, a Mercedes tem 12 mil funcionários. Ela diz que tem 2 mil excedentes. Teria dez. Comparados com o meu três ainda é muito (Saltini, 2016, p. 5).

João Herrmann, por sua vez, destaca como vantagem do consórcio modular o fato deste configurar uma estratégia produtiva que potencializa o caráter 'artesanal' ou tailor made da marca de caminhões Volkswagen, centrado na modularidade radical de seu processo de produção:

[...] O consórcio modular é o início de tudo. Então, já nasce pensando que ele vai ser montado modularmente e cada fornecedor nosso já tem isso na cabeça. Se você montou ele num esquema modular, para desmontar é modular também. Não adianta nada você, depois que montou de uma forma, achar que vai desmontar de outra. Não vai. Vai dar problema. Nós somos muito bem-vistos, todas as pesquisas que a gente faz mostram isso, fala "Pô, o Volkswagen é muito flexível, é um caminhão que faz tudo, você transforma ele, volta e transforma de novo e tal, e ele está lá inteirão" (Herrmann, 2016, p. 13). 
Segundo o modelo teórico das cadeias globais de valor (CGV), quando um produto é modular, como no caso dos caminhões, crescem os níveis de complexidade da transferência de informações necessária à sua produção, fator que pode ser compensado a partir do incremento na capacidade de codificação entre as partes da operação e da capacidade dos fornecedores de atender aos requisitos necessários de produção, proporcionando padronização técnica, simplificação das interações, flexibilidade e nível relativamente baixo de coordenação e de assimetria de poder, como nos casos das cadeias de valor modulares (Gereff; Humphrey; Sturgeon, 2005, p. 86).

Mas a característica mais significativa do consórcio modular é o fato de que a Volkswagen, ao externalizar o processo produtivo, apelando para as competências e responsabilidades das fornecedoras de primeira camada, se restringe à gestão de sua marca, ao desenvolvimento de novos produtos, à organização das vendas e aos serviços de pós-venda. Ou seja, a empresa se concentra nos segmentos mais lucrativos do negócio (Abreu; Beynon; Ramalho, 2006, p. 77).

De fato, como já foi dito, o modelo apresenta uma mudança radical, alterando inclusive o status de "montadora" da Volkswagen. Como analisa Saltini:

A indústria automotiva não é uma indústria de muitos anos, é uma indústria de 120 anos, grosso modo. Nem 120 anos tem. E houve um desenvolvimento muito forte principalmente nos últimos 60 anos. Essa indústria cresceu mesmo nos últimos 60 anos. Vamos chamar assim da década de 50 para cá. No mundo, não estou falando do Brasil não. O que nós éramos no passado? Fabricantes de veículo. Nós éramos fabricantes de veículos. A Volkswagen tinha uma área na Volkswagen de corte e costura. Por quê? Porque todos os bancos eram montados dentro da Volkswagen. As estruturas eram soldadas lá e a tapeçaria era feita dentro da Volkswagen, dentro da Fiat, dentro da GM. Era assim que funcionava. Então nós fabricávamos. A gente recebia o cluster no nosso painel, e toda a montagem do painel, de colocar o quadro de instrumentos, nós fazíamos. Depois de montar uma linha. Aí você avança para uma situação um pouco diferente. Você perde o status de fabricante de veículo, apesar de que a gente ainda chama de fabricante de veículo porque a Volkswagen produz o motor dela mesma, ela estampa as chapas, a maior 
parte das chapas dela, assim como a Fiat, como a Ford, então você ainda chama de fabricante porque... Mas a gente passa por uma nova situação que a gente se transforma no que a gente chama hoje de montadora de veículo. A gente deixa de ser fabricante na essência, e passa a ser montadora. E o que é a montadora? Eu não faço mais banco dentro de casa. Eu compro o banco pronto de um cara que sabe fazer banco. A única coisa que ele faz é banco. Não é? Muitas vezes, até a parte de estamparia você compra de uma empresa. Por exemplo, tem $\mathrm{N}$ empresas que usam a antiga Automotivos da Usiminas, lá em Pouso Alegre, que hoje chama Flama, que é do Grupo Aethra, e estampa a cabine do Cargo. É feita integralmente lá. Aquele Jeep indiano feito no Brasil, Mahindra, que é feito lá pela Bramon, em Manaus, todo monobloco dele, ele vem na chapa nua, mas é feito todo o tratamento superficial, pintura, montagem lá na Automotiva Usiminas e depois vai para Manaus. Pra montar o chassi e aí para acoplar ele novo. Então você passa a ser uma montadora onde você recebe esses componentes e você só monta. E aí você cria uma nova figura chamado sistemista. Mas o que é o sistemista? Ele, na realidade, é um congregador de componentes. Então eu deixo de comprar, por exemplo, o meu painel de instrumentos, o quadro de instrumentos e a caixa de ar e alguém monta isso para mim, traz isso tudo pronto e me entrega pronto esse painel com tudo lá. Com o chicote já passado, tudo. Eu só vou lá, ponho dentro do carro e conecto. Eu pego o banco que vem de outro e ponho lá o banco. Monto o banco, parafuso o banco lá no trilho. Então, eu deixo de ser fabricante para ser montador e crio a figura do sistemista. O que nós fizemos no consórcio modular? Nós fomos além do sistemista, porque, além dele me fornecer o conjunto, ele monta no produto. Então esse passo a indústria não deu. Só nós demos. Não tem ninguém no mundo que faça isso (Saltini, 2016, p. 28-29).

Nessa entrevista, Saltini chama atenção para o fato de que o modelo de consórcio modular pode apontar para uma tendência na indústria automotiva, na qual as empresas detentoras de marca extrapolariam seu status de montadoras. Na realidade, essa configuraria uma terceira transformação, considerando que a noção de 'montadora' advém de uma passagem de um modelo no qual as empresas desenvolviam e fabricavam diretamente seus veículos para um modelo no qual algumas empresas desenvolvem o projeto de veí- 
culo, compram um conjunto de componentes desenvolvidos e fabricados por outras empresas e os montam, compondo o produto final. Se considerarmos que o consórcio modular de Resende é paradigmático, então podemos apontar para uma tendência de divisão pela qual algumas empresas detêm marcas estabelecidas, ficam responsáveis por gerir suas imagens, por desenvolver os produtos e por integrar sistemas, enquanto que um outro conjunto de empresas se especializa no desenvolvimento de componentes e participa diretamente do processo de fabricação.

\section{CONSIDERAÇÕES FINAIS}

Em pouco mais de 120 anos de existência, a indústria automobilística alterou dramaticamente a paisagem urbana e se tornou uma das maiores do mundo, representando parcela significa da economia global. Podemos dizer que o veículo automotor se tornou o principal símbolo do avanço do modo de produção capitalista depois do trem movido a vapor. O carro de passeio se tornou um dos principais objetos de consumo das famílias e até mesmo caminhões e ônibus, apesar de serem bens de capital, possuem nichos de aficionados que acompanham feiras e as últimas novidades. Os modelos de organização da produção dos automóveis se tornaram paradigmas do modelo de produção da indústria como um todo, do fordismo ao toyotismo.

Com o processo de transformação do fenômeno das marcas não foi diferente: desde o Modelo $\mathrm{T}$, atestando a qualidade da produção em massa da Ford, até as atuais marcas de veículos com designs arrojados que despertam paixões e desejos. Atualmente, as marcas do setor estão entre as mais reconhecidas, cobiçadas e valorizadas do mundo, de modo que não existem carros comercializados sem marca.

Ao longo do século XX, a marca deixou de meramente atestar qualidade padronizada de determinados produtos e, a partir da década de 1950, passou a evocar personalidade e estilos de vida em gamas de produtos e em corporações. Em uma terceira fase, a marca foi financeirizada, isto é, traduzida em valores monetários, representando um "ativo intangível" (Willmott, 2010) ou "ativo simbólico" (Norberto, 2004) das corporações nos mercados financeiros. 
A construção e a manutenção desse ativo, porém, demanda articulação e coerência entre múltiplas dimensões da estratégia corporativa, desde a concepção do produto, até sua produção passando pela comunicação e o posicionamento em relação aos concorrentes. A marca cria um fio de continuidade entre as diversas transformações pelas quais passam a corporação e seus produtos ao longo do tempo. Mas como exatamente essa coerência é construída na prática cotidiana das corporações?

Conforme este trabalho buscou demonstrar, a MAN Latin America adotou uma estratégia de mercado dual brand, posicionado suas marcas em relação a seus concorrentes: caminhões da marca MAN em um nicho premium, competindo com Volvo e Scania, e veículos Volkswagen em um nicho bugdet em concorrência com Mercedes e Ford.

A estratégia de produto tem por base o trabalho realizado no setor de marketing: monitoramento do desempenho da concorrência a partir de dados sobre produtos, preços, volumes de venda, dentre outros, e identificação de tendências de comportamento de compra dos consumidores para adequar a linha de produtos às demandas já existentes que não estão supridas pela empresa ou às demandas que ainda estão por vir. Essas demandas são relatadas e encaminhadas à engenharia, que traçam as guidelines do produto. Essa proposta, então, retorna ao marketing, que propõe alterações. Trata-se de um ciclo de várias idas e vindas até que se chegue a um consenso sobre o produto final. As características físicas dos produtos precisam ser coerentemente concebidas com relação aos valores das marcas, como adaptabilidade, e tailor made robustez, no caso da Volkswagen.

A estratégia produtiva da empresa se dá basicamente pelo modelo de consórcio modular, na qual as empresas fornecedoras de peças se responsabilizam diretamente pela montagem do produto, restando somente o controle de qualidade final para a MAN Latin America. A modularidade apresenta coerência com o conceito tailor made da marca Volkswagen. Além disso, apresenta a vantagem da empresa pagar somente por caminhões vendidos e não fabricados, isentando-a de problemas associados a estoque.

$\mathrm{Na}$ intersecção de todas essas dimensões da estratégia corporativa, podemos visualizar a estratégia de marca da MAN Latin 
America. Os conceitos de adaptabilidade e tailor made permeiam todos os processos de posicionamento no mercado, desenvolvimento, comunicação e fabricação dos veículos Volkswagen. A marca dá uma linha de coerência às mudanças na estratégia e, ao mesmo tempo, depende da coerência entre as múltiplas dimensões da estratégia.

O caso analisado permite enxergar que o cerne do trabalho realizado internamente à corporação se dá nos processos de trabalho intelectual (Carchedi, 2011), como aquele realizado no setor de marketing. A estratégia produtiva da MAN Latin America consiste fundamentalmente na externalização da fabricação e montagem. Trata-se de um novo paradigma, que supera inclusive o status de montadora da empresa: ela nem ao menos monta peças fabricadas e desenvolvidas por outras firmas, ela limita-se ao papel de integradora de sistemas e desenvolvedora de produtos. Tal paradigma representa uma reconfiguração na rede global de produção de veículos, na qual empresas líderes buscam cada vez mais controle de ativos intangíveis, como marcas e propriedade intelectual, enquanto que firmas fornecedoras especializam-se na fabricação.

\section{REFERÊNCIAS}

ABREU, A.; BEYNON, H.; RAMALHO, J. R. "A fábrica dos sonhos" da Volkswagen. In: RAMALHO, J. R.; SANTANA, M. A. (Org.). Trabalho e Desenvolvimento Regional. Rio de Janeiro: Mauad X, 2006. p. 71-90.

ANFAVEA. Anuário da Indústria Automobilística Brasileira 2017. São Paulo: ANFAVEA, 2017. Disponível em: <http://www.virapagina. com.br/anfavea2017/>. Acesso em: 13 nov. 2017.

ANFAVEA. Carta da ANFAVEA $n^{\circ}$ 370. Disponível em: <http://www. anfavea.com.br/cartas/carta370.pdf >. Acesso em: 15 nov. 2017.

ANFAVEA. Séries Históricas. Disponível em: <http://www.anfavea.com. br/estatisticas.html>. Acesso em: 15 nov. 2017.

BOAVENTURA, J. C. Marketing Business to Business: estudo de caso de uma concessionária de caminhões. 2011. 105 p. Dissertação (Mestrado em Administração) - Faculdades Pedro Leopoldo, Pedro Leopoldo, 2011. 
CARCHEDI, G. Behind the Crisis: Marx's Dialectics of Value and Knowledge. Leiden: Brill, 2011.

CASTElls, M. A Sociedade em Rede. São Paulo: Paz e Terra, 1999. v. I.

COE, N.; HESS, M. Global production networks, labor and development. Geoforum, v. 44, p. 4-9, 2013.

DE MASI, D. A sociedade pós-industrial. In: DE MASI, D. (Org.). $A$ sociedade pós-industrial. 3. ed. São Paulo: Editora SENAC São Paulo, 2000. p. 11-98.

ERMANN, U. Consumer capitalism and brand fetishism: The case of fashion brands in Bulgaria. In: PIKE, A. (Org.). Brands and Branding Geographies. Cheltenham: Edward Elgar Publishing, 2008. p. 107-124.

FRANCISCO, E. M. V. A comissão enxuta: ação política na fábrica do consórcio modular em Resende. Bauru: EDUSC, 2005.

GEREFFI, G. The Global Economy: Organization, Governance, and Development. In: SMELSER, N.; SWEDBERG, R. (Org.). The Handbook of Economic Sociology. Princeton: Princeton University Press, 2010. p. 160-182.

GEREFFI, G.; HUMPHREY, J.; STURGEON, T. The governance of global value chains. Review of International Political Economy, v. 12, p. 78-104, 2005.

GORZ, A. O imaterial: conhecimento, valor e capital. São Paulo: Annablume, 2005.

HARVEY, D. Condição Pós-Moderna. São Paulo: Edições Loyola, 1989.

HENDERSON, J.et al. Redes de produção globais e a análise do desenvolvimento econômico. Revista Pós Ciências Sociais, v. 8, p. 143-170, 2011.

HERRMANN, J. Entrevista com João Herrmann. Entrevista concedida a Diego Moreira Maggi. São Paulo, 22 jul. 2016.

IEDI. I. Indústria 4.0: A Quarta Revolução Industrial e os desafios para a indústria e para o desenvolvimento brasileiro. Disponível em: $<$ http://www.iedi.org.br/artigos/top/estudos_industria/20170721_ iedi_industria_4_0.html $>$. Acesso em: 30 jul. 2017.

INTERBRAND. 19 MAN - Best German Brands 2015. Disponível em: $<$ http://www.bestgermanbrands.com/en/19/man\#content $>$. Acesso em: 11 dez. 2017.

INTERBRAND. 20 Volkswagen - Best Global Brands 2016. Disponível em: <http://interbrand.com/best-brands/best-global-brands/2017/ 
Marcas e divisão de trabalho na rede de produção automobilística: o caso MAN Latin America.

ranking/volkswagen/>. Acesso em: $11 \mathrm{dez} .2017$

INTERBRAND. Best Global Brands. Disponível em: <http://interbrand.com/ best-brands/best-global-brands/methodology/>. Acesso em: 9 dez. 2017.

KELLER, K. L. Strategy Brand Management: Building, Measuring and Managing Brand Equity. 4. ed. Essex: Pearson Education, 2013

KUTNEY, P. VW cria conselho e sede da Truck \& Bus. Disponível em: $<$ http://www.automotivebusiness.com.br/noticia/22362/vw-criaconselho-e-sede-da-truck--bus>. Acesso em: 17 out. 2017.

LANDRY, C. Cidade Criativa: A história de um conceito. In: REIS, A. C.; KAGEYAMA, P. (Org.). Cidades Criativas: Perspectivas. São Paulo: Garimpo de Soluções, 2011.

LAZZARATO, M. O ciclo da produção imaterial. Trabalho Imaterial: formas de vida e produção de subjetividade. Rio de Janeiro: DP\&A, 2001.

LURY, C. Brands: The logos of the global economy. London and New York: Routledge, 2004.

MAN LATIN AMERICA. Consórcio Modular. Disponível em: <https:// www.man-la.com/institucional/consorcio-modular>. Acesso em: 18 jul. 2016.

MAN LATIN AMERICA. Linha do Tempo. Disponível em: <https:/www. man-la.com/institucional/linha-do-tempo>. Acesso em: 13 nov. 2017.

MAN LATIN AMERICA. Linha Volksbus 2004: satisfação sob medida para empresários e passageiros. Disponível em: <http://vwtbpress. com.br/noticia_imp.asp?n=151>. Acesso em: 9 out. 2017.

MAN LATIN AMERICA. Produtos Volkswagen. Disponível em: <https:// www.man-la.com/produtos-volkswagen/>. Acesso em: 15 nov. 2017.

NEGRI, A.; HARDT, M. Império. São Paulo: Record, 2001.

NEGRI, A.; LAZZARATO, M. Trabalho imaterial e subjetividade. Trabalho Imaterial: formas de vida e produção de subjetividade. Rio de Janeiro: DP\&A, 2001.

NORBERTO, E. Estratégias corporativas de marcas e estratégias sociais de diferenciação: uma análise a partir do automóvel. Revista Tempo Social, v. 16, 2004.

PAUlA, E. K. Pólo Automotivo Sul Fluminense : novos rumos para o desenvolvimento econômico da região. 2015. 190 p. Dissertação (Mestrado em Políticas Públicas, Estratégias e Desenvolvimento) Universidade Federal do Rio de Janeiro, Rio de Janeiro, 2015. 
RAMALHO, J. R.; SANTANA, M. A. A indústria automobilística no Rio de Janeiro: relações de trabalho em um contexto de desenvolvimento regional. In: NABUCO, M. R.; NEVES, M.; CARVALHO NETO, A. (Org.). Indústria automotiva: a nova geografia do setor produtivo. Rio de Janeiro: DP\&A, 2002.

RAMALHO, J. R.; SANTOS, R. Estratégias corporativas e de trabalho no Brasil: uma análise de 4 grupos multinacionais. In: XIV ENCONTRO NACIONAL DA ABET, 2015, Campinas. Anais... Campinas, 2015.

RAMALHO, J. R.; SANTOS, R. Estrategias Corporativas y Relaciones de Trabajo en Empresas Transnacionales Norteamericanas y Mexicanas en Brasil. In: GARZA, E. DE LA; ROMO, M. (Org.). Configuraciones Productivas y Relaciones Laborales en Empresas Multinacionales en América Latina. 1. ed. Ciudad de Mexico: UAM; Gedisa, 2017. p. 317-373.

REVISTA CARGA PESADA. Mercedes-Benz reconquista liderança no mercado de caminhões. Revista Carga Pesada, 2 jan. 2017. Disponível em: <http://cargapesada.com.br/2017/01/02/mercedesbenz-reconquista-lideranca-no-mercado-de-caminhoes/>. Acesso em: 14 nov. 2017.

SALTINI, M. Entrevista com Marco Saltini. Entrevista concedida a José Ricardo Ramalho, Rodrigo Santos e Raphael Lima. Rio de Janeiro, 7 jun. 2016.

SANTOS, R. A Construção Social da Região: Desenvolvimento Regional e Mobilização Sóciopolítica no Sul Fluminense. 2006. 169 f. Dissertação (Mestrado em Sociologia e Antropologia) Universidade Federal do Rio de Janeiro, Rio de Janeiro, 2006.

SANTOS, R. Redes de Produção Globais (RPGs): Contribuições conceituais para a pesquisa em ciências sociais. Revista Pós Ciências Sociais, v. 8, n. 15, p. 127-142, 2011.

SCHMITT, B. It's Official: Volkswagen Is World's Largest Automaker In 2016. Or Maybe Toyota. Disponível em: <https://www.forbes. $\mathrm{com} /$ sites/bertelschmitt/2017/01/30/its-official-volkswagen-worldslargest-automaker-2016-or-maybe-toyota/\#40514f4176b0>. Acesso em: 27 nov. 2018.

VISENTAINER, K. Entrevista com Kátia Visentainer. Entrevista concedida a Diego Moreira Maggi. São Paulo, 15 ago. 2016.

VOLKSWAGEN AG. Volkswagen creates integrated commercial vehicles group. Disponível em: <https://www.volkswagen-media-services. 
com/en/detailpage/-/detail/Volkswagen-creates-integratedcommercial-vehicles-group/view/2247914/>. Acesso em: 17 out. 2017.

WILLMOTT, H. Creating "value" beyond the point of production: branding, financialization and market capitalization. Organization, v. 17, n. 5, p. $517-542,1$ set. 2010.

YÚDICE, G. A conveniência da cultura: usos da cultura na era global. Belo Horizonte: Editora UFMG, 2004. 